Florida International University FIU Digital Commons

\title{
A Philosophical Inquiry into the Role of Universities in American Democratic Society
}

Justin W. Taylor

Florida International University, jtayl136@fiu.edu

DOI: $10.25148 /$ etd.FIDC006898

Follow this and additional works at: https://digitalcommons.fiu.edu/etd

Part of the Higher Education Commons

\section{Recommended Citation}

Taylor, Justin W., "A Philosophical Inquiry into the Role of Universities in American Democratic Society" (2018). FIU Electronic Theses and Dissertations. 3738.

https://digitalcommons.fiu.edu/etd/3738

This work is brought to you for free and open access by the University Graduate School at FIU Digital Commons. It has been accepted for inclusion in FIU Electronic Theses and Dissertations by an authorized administrator of FIU Digital Commons. For more information, please contact dcc@fiu.edu. 


\section{FLORIDA INTERNATIONAL UNIVERSITY}

Miami, Florida

\section{A PHILOSOPHICAL INQUIRY INTO THE ROLE OF UNIVERSITIES IN AMERICAN DEMOCRATIC SOCIETY}

A thesis submitted in partial fulfillment of the requirements for the degree of MASTER OF SCIENCE in HIGHER EDUCATION ADMINISTRATION

by

Justin Wayne Taylor 
TO: Dean Michael Heithaus

College of Arts, Sciences and Education

This thesis, written by Justin Wayne Taylor, and entitled A Philosophical Inquiry into the Role of Universities in American Democratic Society, having been approved in respect to style and intellectual content, is referred to you for judgement.

We have read this thesis and recommend that it is approved.

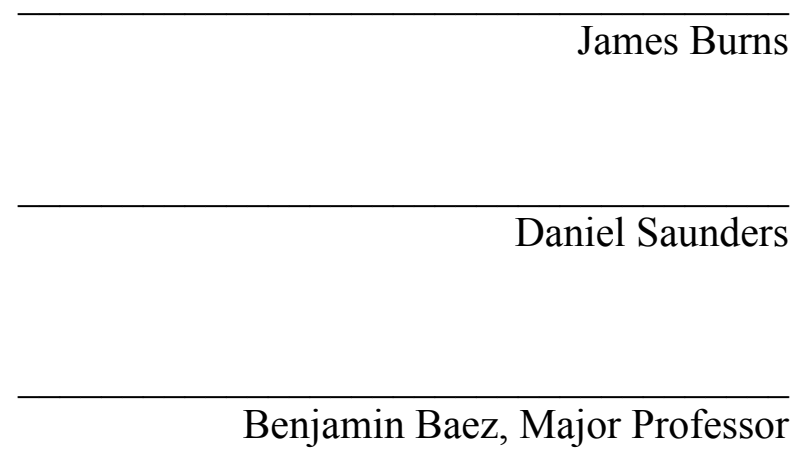

Date of Defense: June 28, 2018

The thesis of Justin Wayne Taylor is approved.

Dean Michael Heithaus

College of Arts, Sciences and Education

Andrés G. Gil

Vice President for Research and Economic Development

and Dean of the University Graduate School

Florida International University, 2018 


\title{
ABSTRACT OF THE THESIS \\ A PHILOSOPHICAL INQUIRY INTO THE ROLE OF UNIVERSITIES IN AMERICAN DEMOCRATIC SOCIETY
}

\author{
by \\ Justin Wayne Taylor \\ Florid International University, 2018 \\ Miami, Florida \\ Professor Benjamin Baez, Major Professor
}

The infusion of market-logic has undermined American universities as democratic institutions. This issue was examined through an analysis of what role universities play in democratic governance. As a philosophical inquiry, the data were seminal texts from political science, education, and philosophy, such as those by Alexis de Tocqueville, John Dewey, and Henry Giroux. The most salient theme unveiled by this study was how central universities are to functional democracy, both as key fixtures and critics. However, universities have adopted market-logic ideologies, which inhibit universities' abilities to function as democratic institutions. The study concludes by calling for a reinvigoration of the public, requiring universities to maintain a public nature. Such transparency lives in tension with neoliberal efforts to privatize public institutions, so universities must provide spaces for debates on that tension. In this way, universities will be able to embody the democratic dispositions necessary for supporting and defending democratic values. 


\section{TABLE OF CONTENTS}

CHAPTER

PAGE

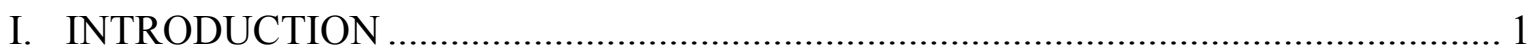

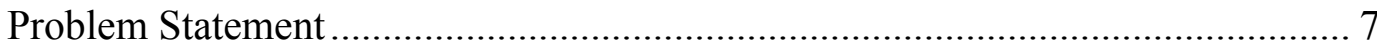

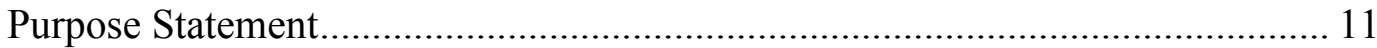

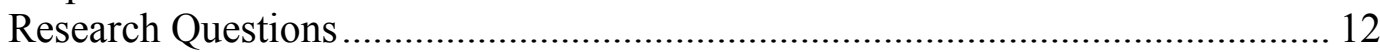

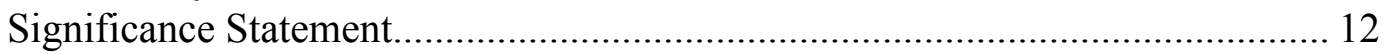

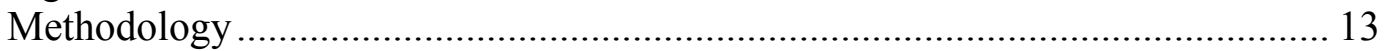

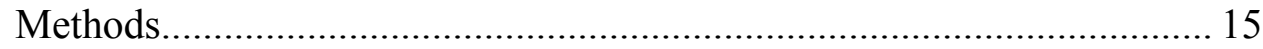

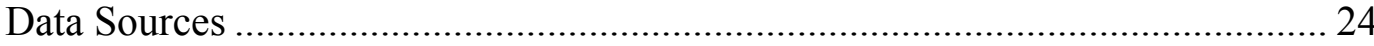

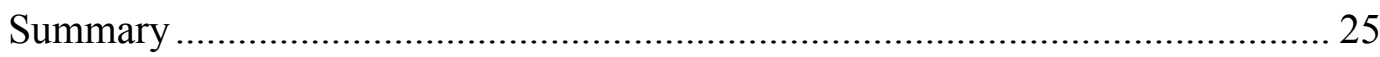

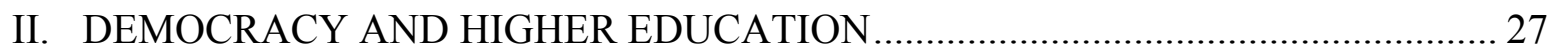

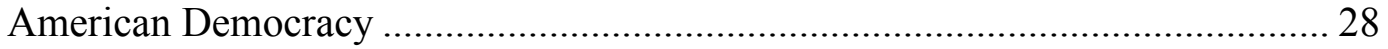

The Public in a Democratic Society................................................................... 32

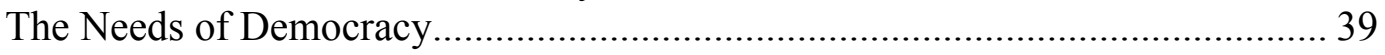

Reducing the Level of Unemployment .................................................... 41

Social Insurance and Social Expenditures ............................................... 42

Social Citizenship ……………………........................................... 42

Progressive Taxation to Finance the Welfare State …………………....... 43

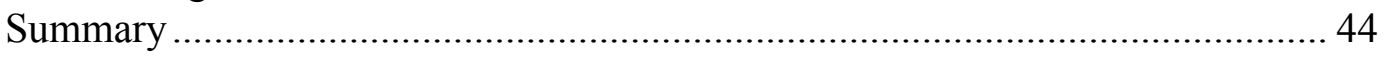

III. THE EARLY DAYS OF AMERICAN HIGHER EDUCATION …….......................46

Higher Education in the Late $19^{\text {th }}$ and Early $20^{\text {th }}$ Century................................... 49

Corporatization of Higher Education..................................................... 54

Higher Education in the $20^{\text {th }}$ Century ………………........................................ 57

The Wisconsin Idea............................................................................. 58

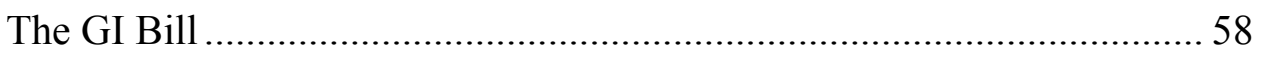

Academic Freedom and Academic Tenure.............................................. 60

Professionalism of Higher Education ..................................................... 62

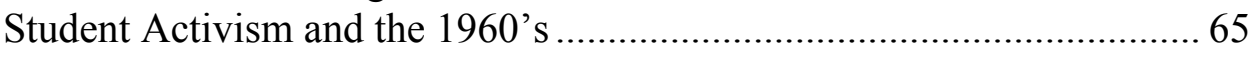

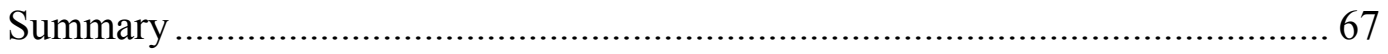

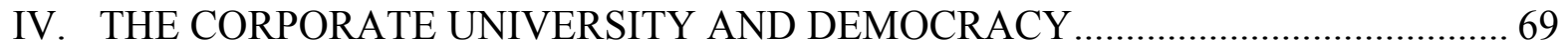

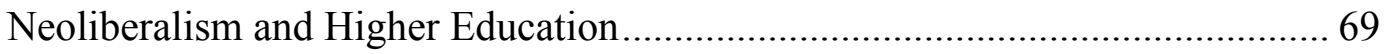

Excellence Through Performance-Based Funding .............................................. 72

Measuring the Corporate University............................................................... 75

Corporate Universities and the Public ........................................................... 80

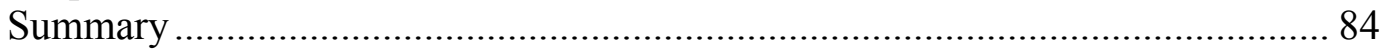


V. FINAL CONCLUSIONS AND IMPLICATIONS ........................................... 86

What are the Issues Currently Facing Democracy? ............................................ 86

What Role do Universities Play in Remedying the Current Crisis Faced by

Democracy? ..................................................................................... 87

What Role Should Universities Play in Democratic Governance?..................... 88

What Role do Universities Play in American Democracy? ............................... 90

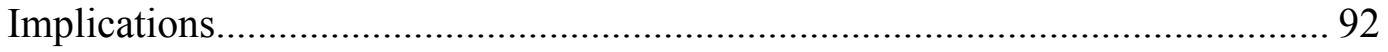

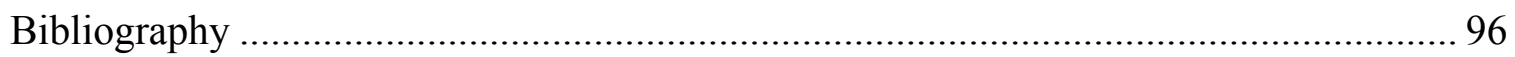




\section{CHAPTER I}

\section{INTRODUCTION}

Democracy is the ideal of equal and collective rule by the people, but that ideal has always faced a crisis. Today, explicit attempts are being made by politicians to prevent participation in democracy by disenfranchising groups of people from elections, discrediting a free press vital to American democracy, and coordinating campaigns of intimidation and slander against their opponents. Neoliberalism, or practices reducing all phenomena to economic calculation, is continuing this assault on democracy via concerted efforts to privatize public services, and in so doing, close off that on which the public can collectively rule. ${ }^{1}$ While democracy may be said to be always in crisis, today's crisis of democracy is indicative of the culmination of decades of neoliberal ideology infiltrating and subverting virtually every American institution key to a functional democracy. $^{2}$

Not least among those institutions under attack by neoliberalism are American universities. ${ }^{3}$ Higher education in the U.S. has historically been viewed as institutions which promote social mobility, and thus democracy, by serving the needs of the expanding frontier, addressing technological requirements for the farming and working

\footnotetext{
${ }^{1}$ Wendy Brown, Undoing the Demos: Neoliberalism's Stealth Revolution (Brooklyn, NY: Zone Books, 2015), 17.

${ }^{2}$ Henry A. Giroux, Neoliberalism's War on Higher Education (Chicago, IL: Haymarket Books, 2014), 7.

${ }^{3}$ Ibid., 16.
} 
classes, and educating the public in state universities. ${ }^{4}$ During the $20^{\text {th }}$ century, universities, in particular, expanded their democratic mission by significantly expanding the population and demographics attaining a college degree through the GI Bill. ${ }^{5}$ Not only did universities act as democratic agencies by providing mass college education, but they were tasked with educating and producing trained graduates who would work to serve the welfare state and other public sector jobs vital to the well-being of the many, not just a few. ${ }^{6}$ While elements of this public mandate still exist, American universities are now increasingly a part of a scheme to provide mere job training to the masses. This training is done on behalf of employers, but students are the ones paying for their job training, not those employers. As such, higher education is becoming more intensely commodified and privatized. This intense commodification has altered the core moral work of universities to serve the public; now their core work is financial, and the aims of university education are closely tied to the marketplace, while the ability of the public to offer voices on how universities should function is constrained.

Commodification is not new to higher education. American institutions of higher education started off as private, and from their inception, they sought revenue streams from local partners and tried to convince prospective students that each had the best

\footnotetext{
${ }^{4}$ Frederick Rudolph, The American College and University: A History (Athens, GA: The University of Georgia Press, 1990), 62-65.

${ }^{5}$ George Fallis, Multiversities, Ideas, and Democracy (Toronto, Canada: University of Toronto Press, 2007), 84-85.

${ }^{6}$ Ibid., 85.
} 
"value" education. ${ }^{7}$ In fact, a century ago Thorstein Veblen published his 1918 critique of the corporatization of American universities in The Higher Learning in America, which came after several decades of other scholars offering similar analyses. ${ }^{8}$

While issues regarding the corporatization of American universities have been reflected upon for at least a century, what has changed recently is the intensification of this market-thinking and how universities consider their "value" strictly in terms of the market. Students are increasingly regarded as "customers," and universities are now "service providers" forced to position themselves as products with the highest standards of "excellence" on the market. ${ }^{9}$ This conceptualization is proving to be destructive not only to universities and higher education but also to the broader democratic institutions of which they are a part.

Free-market logic demands a rational consumer, homo economicus, a selfinterested individual who understands the product he is buying and the value of that product in the broader market. ${ }^{10}$ Under this orientation college students are expected to understand the value of their particular degrees fully, the value of an education at one university versus another, and the value of university education in general. Those with a

\footnotetext{
${ }^{7}$ Rudolph, Multiversities, Ideas, and Democracy, 197-199.

${ }^{8}$ Thorstein Veblen, The Higher Learning in America: A Memorandum on the Conduct of Universities by Businessmen, Annotated ed. (Baltimore, MD: John Hopkins University Press, 2015), 2.

${ }^{9}$ Daniel Saunders, "Exploring a Customer Orientation: Free-Market Logic and College Students," The Review of Higher Education 37, no. 2 (Winter 2014): 197-219; Bill Readings, The University in Ruins (Cambridge, MA: Harvard University Press, 1996), 21-43.

${ }^{10}$ Michel Foucault, The Birth of Biopolitics: Lectures at the Collège de France 1978-1979, ed. Michel Senellart (New York, NY: Palgrave Macmillan, 2008), 268.
} 
bachelor's degree generally see lower unemployment rates than high school graduates, about $2.5 \%$ to $5.3 \%$ respectively in January $2016 .{ }^{11}$

Furthermore, in 2017, college graduates had a weekly median income that was over $65 \%$ higher than that of high school graduates. ${ }^{12}$ However, while employment rates and average salaries are higher for college graduates than non-college graduates, there is no real assurance that the increased income will be enough to offset the debt accrued by attending college. According to the Pew Research Center, about 44 million graduates amassed over $\$ 1.3$ trillion in student loan debt as of June 2017 , and that number is only expected to rise. ${ }^{13}$ This national debt comes to an average of nearly $\$ 30,000$ of debt per person - a debt that will take college graduates decades to pay off. While increased lifetime earnings may be enough to offset this debt, the latter ensures that recent graduates become beholden to their employers because they cannot afford to lose their jobs. This atmosphere makes it difficult for those employees to take risks, question authority or policies, or generally assert themselves in the workplace. They are rendered more subservient to, and reliant upon, their employers despite their college education and the supposed capital that conveys.

\footnotetext{
${ }^{11}$ Bureau of Labor Statistics, U.S. Department of Labor, Unemployment Rate 2.5 Percent for College Grads, 7.7 Percent for High Schools Dropouts, January 2017, accessed on January 10, 2018, https://www.bls.gov/opub/ted/2017/unemployment-rate-2-point-5-percent-for-college-grads-7-point-7percent-for-high-school-dropouts-january-2017.htm.

${ }^{12}$ Bureau of Labor Statistics, U.S. Department of Labor, High school graduates who work full time had median weekly earnings of \$718 in second quarter, February 2017, accessed on April 10, 2018, https://www.bls.gov/opub/ted/2017/high-school-graduates-who-work-full-time-had-median-weeklyearnings-of-718-in-second-quarter.htm.

${ }^{13}$ Anthony Cilluffo, "5 Facts About Student Loans," Pew Research Center, August 24, 2017, accessed January 10, 2018, http://www.pewresearch.org/fact-tank/2017/08/24/5-facts-about-student-loans.
} 
As the average student debt climbs, students and their families face even more pressing decisions about their future and the education they want to pursue. Different majors have always afforded different financial opportunities, but now students must consider what major will help them pay off the debt they accrue trying to earn their degree. Lifetime earnings for STEM and business majors greatly outweigh those of teachers, social workers, and public administrators. ${ }^{14}$ Students must ask themselves if their first jobs out of college, such as teaching, which only paid an average salary of $\$ 38,617$ nationally in $2016-2017$, will be enough to pay off their $\$ 20,000, \$ 30,000$, or $\$ 40,000+$ loans. ${ }^{15}$ The nine highest-earning majors are all some variant of engineering, and the vast majority of the top 30 earning majors are either in STEM or business fields, pushing students disproportionately in those directions. ${ }^{16}$ As student debt rises, it will soon be untenable for most students to pursue subject areas related to culture, education, or fields that support the welfare state, which were deemed necessary for democracy in the last century. ${ }^{17}$

However, this conversation is not solely about rising student debt for itself, but about the damage done by it and the other effects of unquestioned market logic in higher

\footnotetext{
${ }^{14}$ Brad Hershbein and Melissa Kearney, "Major Decisions: What Graduates Earn Over Their Lifetimes," The Hamilton Project, September 29, 2014, accessed January 12, 2018, http://www.hamiltonproject.org/assets/legacy/files/downloads_and_links/Major_Decisions_Lifetime_Ear nings_by_Major.pdf.

${ }^{15}$ National Education Association, “2016-2017 Average Starting Teacher Salaries by State,” December 2017, accessed March 26, 2018, http://www.nea.org/home/2016-2017-average-starting-teacher-salary.html.

${ }^{16}$ Hershbein and Kearney, "Major Decisions."

${ }^{17}$ Fallis, Multiversities, Ideas, and Democracy, 103.
} 
education. In modern education, students themselves come to expect less from their education and their larger university experience in a variety of ways. Administrators take from students the responsibility of dictating university culture and norms, ultimately habituating students into internalizing the notion that administrative bureaucracy is responsible for governance - not the actual public. ${ }^{18}$ Teaching as a profession has been undermined so that "real world experience" matters far more than the ability to teach and develop students. ${ }^{19}$ Universities, as agents of socialization, appear to be indoctrinating a majority of their members toward a neoliberal ideology, which represents yet another limitation on the potential for democracy. ${ }^{20}$

Michael Apple has written extensively about this socialization and what he calls the "hidden curriculum." ${ }^{21}$ Never explicitly stated, this curriculum is the result of countless factors that influence individuals and their ways of thinking. Socialization in education, notably higher education, should not be thought of as absolute or as enough to undo socialization from all other sources (family, friends, community, etc.). Instead, education reinforces socialization that occurs elsewhere, often toward societal norms. Apple argues how the hidden curriculum is socializing students towards a neoliberal

\footnotetext{
${ }^{18}$ Valerie Strauss, "How Today's College Students Infantilize Themselves," Washington Post, May 27, 2017, accessed on January 24, 2018, https://www.washingtonpost.com/news/answersheet/wp/2017/05/27/how-todays-college-students-infantilize-themselves/?utm_term=.c180c3613ab5.

${ }^{19}$ Giroux, Neoliberalism's War on Higher Education, 29-30.

${ }^{20}$ Michael Apple, Ideology and Curriculum, $3^{\text {rd }}$ ed. (New York, NY: RoutledgeFalmer, 2004), 170-171.

${ }^{21}$ Ibid., 77-97.
} 
ideology, and how this undermines the idea of a public by coercing individuals to only view themselves as private citizens, not as belonging to a broader public. ${ }^{22}$

These factors and others are further removing individuals from the ability to take charge of the systems to which they belong. Instead, they become compliant parts of a system that does not serve them. To understand this idea better, we can look to Alexis de Tocqueville, who cautioned against the "tyranny of the majority" in his work, Democracy in America. ${ }^{23}$ Following the work of others, I take this a step further by cautioning against what I see as the tyranny of the compliant majority. ${ }^{24}$ The effects of neoliberalism throughout society benefit the wealthiest among us, and they use their wealth and influence to socialize and condition the masses to accept it through the reduction of expectations. Universities are becoming complicit in that socialization and are now working to create a compliant majority who rules tyrannically, and often unwittingly, on behalf of an elite minority. The potential for democracy is being subverted in part because the majority is being coerced into acting against themselves.

\section{Problem Statement}

Democracy has always contained internal contradictions and tensions in the U.S. because of the manner in which it has manifested itself. Theoretical democracy requires direct rule by the entire population, but the practical barriers to this are such that

\footnotetext{
${ }^{22}$ Michael W. Apple, "Creating Difference: Neo-Liberalism, Neo-Conservatism and the Politics of Educational Reform," Educational Policy 18, no. 1 (March 2004): 12-44.

${ }^{23}$ Alexis de Tocqueville, Democracy in America, Signet Classics ed. (New York, NY: Signet Classics, 2010), 4.

${ }^{24}$ Walter Lippmann, The Phantom Public, (New Brunswick, NJ: Transaction Publishers, 1993), 145.
} 
compromises have to be made and the position of rule and governance handed over to a relative few. As such, the U.S. employs a representative system, otherwise known as a republic, whereby the populace delegates its authority to elected officials tasked with ruling in the best interests of their electorate. A close facsimile of democracy is maintained so long as the populace retains a high level of trust in those representative systems. However, in the U.S. today there is severe distrust in the fundamental institutions of American democracy. For example, there is a lack of confidence in the mainstream media, ${ }^{25}$ concern over voter suppression via gerrymandering, ${ }^{26}$ fear of interference in the 2016 election, ${ }^{27}$ and a decrease of public confidence in higher education. ${ }^{28}$ If George Fallis is correct that American universities are central to a functioning democracy, then questions about the validity of democracy are also ones

\footnotetext{
${ }^{25}$ Art Swift, "Americans' Trust in Mass Media Sinks to New Low," Gallup, September 14, 2016, accessed October 29, 2017, http://news.gallup.com/poll/195542/americans-trust-mass-media-sinks-new-low.aspx; "Further Decline in Credibility Ratings for Most News Organizations," Pew Research Center, August 16, 2012, accessed October 29, 2017, http://www.people-press.org/2012/08/16/further-decline-in-credibilityratings-for-most-news-organizations.

${ }^{26}$ Chao Fan et al., "A Spatiotemporal Compactness Patter Analysis of Congressional Districts to Assess Partisan Gerrymandering: A Case Study with California and North Carolina," Annals of the Association of American Geographers 105, no. 4 (July 2015): 1-18, accessed October 29, 2017, http://dx.doi.org/10.1080/00045608.2015.1039109.

${ }^{27}$ Ryan Wilkinson, "Russia investigation: What is a US grand jury and how does it work?" The Independent, August 4, 2017, accessed October 29, 2017, https://www.independent.co.uk/news/world/americas/us-politics/russia-investigation-us-grand-jury-whatis-it-how-work-robert-mueller-donald-trump-public-us-a7876086.html.

${ }^{28}$ David R. Johnson and Jared L. Peifer, "How Public Confidence in Higher Education Varies by Social Context," Journal of Higher Education 88, no. 4 (April 2017): 619-644, accessed October 29, 2017, https://doi.org/10.1080/00221546.2017.1291256.
} 
about higher education. ${ }^{29}$ These concerns have been increasing consistently since the last decade, and there is no reason to believe that the problem will resolve itself any time soon.

This current crisis of democracy results from the degree to which market logic has come to dominate institutions of democracy, especially universities. This crisis comes after decades of dissolution of the American "public" through consistent and effective efforts to privatize public institutions. These efforts are largely spearheaded by powerful lobbyist groups such as the American Legislative Exchange Council (ALEC) that proposes significant legislative changes across all 50 state governments. ${ }^{30}$ ALEC regularly supports and promotes privatization efforts such as charter schools and school voucher programs for both $\mathrm{K}-12$ and higher education that siphon public funds into private schools that enjoy less regulation than public schools allowing for less public oversight. On its website, ALEC states its support for "Innovative, parent-empowering choices such as charter schools, voucher programs, tax credit scholarships, homeschool, and education savings accounts. ${ }^{.31}$

Their priorities are further highlighted by the most recent ALEC Report Card, which assigns each state and the District of Columbia an education policy grade "based on six factors: state academic standards, charter schools, homeschool regulation burden,

\footnotetext{
${ }^{29}$ Fallis, Multiversities, Ideas, and Democracy, 61.

${ }^{30}$ Gordon Lafer, "The Corporate Assault on Higher Education," The Chronicle of Higher Education, April 30, 2017, accessed on August 28, 2017, https://www.chronicle.com/article/The-Corporate-Assaulton/239902.

31 “Issues/Education,” ALEC, accessed April 12, 2018, https://www.alec.org/issue/education.
} 
private school choice, teacher quality, and digital learning." ${ }^{.32}$ The other primary feature of the report is a school choice ranking for each state's school choice program based on the "program's size and scope, purchasing power in the educational marketplace, and flexibility and freedom. ${ }^{, 33}$ Arizona received the highest education policy grade as well as the highest school choice program ranking (Florida was second in both categories). By comparison, California ranked $25^{\text {th }}$ in school choice with an education policy grade of a C, and Nebraska was last in both categories. ${ }^{34}$ Curiously, while the report includes graduation rate and average-class size as supplemental information, ALEC makes it clear that neither statistic is taken into account in its grades or rankings. Arizona and Florida both had graduation rates of $63 \%$, while California and Nebraska saw graduation rates of $82 \%$ and $94 \%$, respectively. ${ }^{35}$

In a report titled, "Report Card on American Education: Ranking State K-12 Performance, Progress and Reform," one might expect graduation rates and average-class sizes (which were similarly lopsided) to be more significant, highlighting how little they matter to ALEC relative to the ability to use public funds for private schools. This priority is significant as ALEC is a major force in state legislatures across the country.

\footnotetext{
${ }^{32}$ Inez Feltscher Stepman, "Report Card on American Education: $22^{\text {nd }}$ Edition," American Legislative Exchange Council, January 24, 2018, accessed April 12, 2018, https://www.alec.org/app/uploads/2018/01/2017-ALEC-Report-Card_Final_WEB.pdf.

${ }^{33}$ Ibid.

${ }^{34}$ Ibid.

${ }^{35}$ Ibid.
} 
Approximately "200 of its sponsored bills are adopted every year in state legislatures."36 That level of influence means that the neoliberal ideology that governs ALEC has a significant impact on American education as well.

The extreme and unprecedented nature of neoliberalism's takeover of higher education ought to concern all parties, and especially those who view universities as institutions of democracy, which should offer more than job training and credentials. However, before anything can be done to address this problem research must explore and understand the problem. While empirical research might explain part of the problem, a conceptual analysis must examine the ontological and epistemological bases for these problems. In so doing, we may engage in moral or ethical arguments regarding democracy and its relation to education.

\section{Purpose Statement}

The purpose of this thesis is to offer a critique of how universities function in relation to American democratic society as well as how universities may better promote democracy through the socialization that occurs on their campuses. By examining historical and current texts dealing with democracy and higher education, I hope to put forth answers to moral and ethical questions about the obligation universities have to society. This study aims to call on universities to engage consciously in the work of socializing their students to be democratically-engaged citizens. For this to occur students must first realize themselves as public citizens, not solely private individuals whose only

\footnotetext{
${ }^{36}$ Lafer, "The Corporate Assault on Higher Education."
} 
concerns are those of self-interest. ${ }^{37}$ For universities to accomplish this, they will have to reconsider the education they provide for students that is now little more than transactional coursework emphasizing skill acquisition. Instead, what is needed is a thorough understanding of the environment in which students learn, the logic that governs that environment, and the public (or private) nature of governing entities. Among John Dewey's most salient arguments on democracy is the imperative for citizens to create and maintain public spaces for such understanding to occur, and I believe that universities have a responsibility to embody that imperative.

\section{Research Questions}

The primary question subtending this study is: What role do universities play in American democracy? Other derivative questions addressed by this study are:

1. What are the issues currently facing American democracy?

2. What role do universities play in remedying the current crisis faced by democracy?

3. What role should universities play in democratic governance?

By asking these questions, this study hopes to offer insight into fundamental ideas about how anti-democratic power regimes require a redefinition of the relationship between higher education and other democratic institutions.

\section{Significance Statement}

This thesis hopes to address the national and global crisis of democracy by illuminating the link between democratic institutions and higher education. Such a

\footnotetext{
${ }^{37}$ John Dewey, The Public and its Problems, (Athens, OH: Swallow Press, 1954), 28-29.
} 
relationship could have a profound impact on the role universities are viewed to have in society as well as a significant influence on the role of government in higher education, university missions, curriculum, and extracurricular activities. Furthermore, this study may offer a launch point for further research in the fields of education, political science, and public policy. Finally, this study will contribute to philosophical inquiry in education research by providing alternatives to empiricism in the field of education, which sorely lacks reflection on its theoretical assumptions.

\section{Methodology}

Because any argument about the nature of democracy, or the role universities will play in it, is inherently an axiological one, this study will offer philosophical inquiry to address the research questions. Axiology is the branch of philosophy concerned with values. Burbules and Warnick defined philosophical inquiry as a "method of generating knowledge and perspective." ${ }^{38}$ Instead of trying to generate empirical knowledge, this form of inquiry uses logical reasoning to provide an understanding of "why" questions that inform value-laden human practice. Philosophical inquiry, through rigorous critique and analysis, may come to a satisfactory conclusion to axiological questions.

As Burbules and Warnick discuss, philosophical inquiry is deeply rooted in the tradition of education research dating back to the days of Socrates and Plato. However, in recent years education research has come to overly privilege empirical research through a "what works" mentality that shows little consideration for the ends to which education is

\footnotetext{
${ }^{38}$ Nicholas C. Burbules and Bryan R. Warnick, "Philosophical Inquiry," in Handbook of Complementary Methods in Education Research, ed. Judith L. Green, Gregory Camilli, and Patricia B. Elmore (New York, NY: Routledge, 2006), 489.
} 
working. ${ }^{39}$ This conflict is discussed in further detail by Benjamin Baez and Deron Boyles through their discussion of Scientific Research in Education (SRE), a 2002 report from the National Research Council (NRC). ${ }^{40}$ In discussing SRE, Baez and Boyles discuss the kind of reading and research necessary to properly examine the report. They state,

Instead of focusing too much on the supposed intended meaning of SRE, which will only push us toward the tedious task of offering yet another philosophy on the science of education, we spend much of our energies, not on determining what the text means but what makes it possible, and, in turn, what it makes possible. ${ }^{41}$ It is in that spirit which this study is conducted. Instead of offering a new theory of democratic education, the study in this thesis seeks to better understanding of what led to the current state of higher education as relates to democracy (what made it possible) and some of the potential outcomes of higher education as relates to democracy (what it makes possible). This argumentation positions us better to make more ethical and moral arguments regarding universities and democracy.

That spirit of inquiry is also the justification for conducting this study as a philosophical inquiry. In discussing education research Burbules and Warnick offer the

\footnotetext{
${ }^{39}$ Ibid.

${ }^{40}$ Benjamin Baez and Deron Boyles, The Politics of Inquiry (Albany, NY: State University of New York Press, 2009), vii.

${ }^{41}$ Ibid.
} 
following commentary regarding the necessity for research which addresses these larger concerns,

In a time of a severe undersupply of people wanting to become teachers and stunningly low rates of retention for those who enter this field, the crisis confronting education today is not a lack of "how to" directives, but a lack of meaning and satisfaction attracting new teachers into the profession and keeping them in for reasons beyond a paycheck. ${ }^{42}$

This issue is not solely confined to K-12 education as Jonathan Malesic chronicled in his tale of burnout, which ultimately led to his leaving a tenured faculty position at the age of 40. In an article for The Chronicle of Higher Education, he credited, "the three main components of burnout: exhaustion, cynicism, and a sense of professional ineffectiveness." ${ }^{43}$ Malesic's tale is a familiar one, and a scroll through the comments section of that article reveals that numerous individuals were experiencing very similar difficulties. A common theme among all of them is one of growing apathy and a feeling of pointlessness to what they were doing in their work.

\section{Methods}

Burbules and Warnick discuss several "methods" of philosophical inquiry but are quick to point out that they are not applied as mechanically as methods in other research methodologies and that the term method is used for simplicity (they are equally "moves"

\footnotetext{
${ }^{42}$ Burbules and Warnick, "Philosophical Inquiry," 489.

${ }^{43}$ Jonathan Malesic, "The 40-Year-Old Burnout," Chronicle of Higher Education, October 5, 2016, accessed April 13, 2018, https://www.chronicle.com/article/The-40-Year-Old-Burnout/237979.
} 
or "strategies"). ${ }^{44}$ They also note that these methods are general in philosophical inquiry and do not belong to any particular school of thought, permitting their employment in this study (pg. 490). The following section will discuss methods of philosophical inquiry generally and those employed explicitly in this study.

Burbules and Warnick outlined ten methods of philosophical inquiry in education research. Here, I will examine each method and its uses followed by a description of how the particular methods employed in this study will provide the tools necessary to answer the stated research questions.

1. Philosophical inquiry analyzes a term or concept, showing its multiple uses and meanings, for the primary purpose of clarification (pp. 491-492).

Scholarly research sometimes contains terms or ideas that at first appear to be clear and self-evident - requiring no elaboration of what is meant or implied - when, in reality, there is an ambiguity that allows for those discussing the term or concept to be unknowingly discussing two very discrete ideas. For example, later in this thesis, I analyze the notion of the "public," a term which may appear to be rather straightforward. However, many scholars have understood that term to hold different meanings in different contexts. To properly discuss what is meant when I refer to the "public" it is prudent first to clarify what is being assumed when using that term. Annette Rottenberg referred to these assumptions as "warrants," or beliefs that we take for granted. ${ }^{45}$ Sometimes warrants do not have to be explicitly stated, but it is often worthwhile to do so

\footnotetext{
${ }^{44}$ Burbules and Warnick, "Philosophical Inquiry," 490; Further page citations in text.

${ }^{45}$ Annette T. Rottenberg, The Structure of Argument, $2^{\text {nd }}$ ed. (Boston, MA: Bedford Books, 1997), 179.
} 
as Rottenberg suggests that, "All our claims, both formal and informal, are grounded in warrants or assumptions that the audience must share with us if our claims are to prove acceptable." 46

2. Philosophical inquiry is an ideological or a deconstructive critique of a term or concept, identifying internal contradictions or ambiguities in uses of the term and a disclosure of partisan effects the term has in popular discourses. ${ }^{47}$

Deconstruction of a term or concept is an important philosophical tool to uncover the hidden biases, distortions, or contradictions within a term or concept. The term "democracy" is one such term that has been closely scrutinized for its various meanings and ideas given the context in which it was used. Deconstruction uncovers, among other things, biases inherent in our language, and it is through those deconstructions that philosophers question, critique, and, if necessary, seek to change or remedy those biases. Many texts read for this study offer deconstructions on terms such as "public" and other salient terms and ideas.

3. Philosophical inquiry explores the hidden assumptions underlying a particular view or school of thought (pp. 493-494).

This method is understood to be a more generalized form of the previous method. Rather than closely scrutinizing a term or concept, this method analyzes entire theories or discourses. Again, this study does not utilize this particular method as such but heavily relies on other texts which have done so. Many of the texts engaged with for this study

\footnotetext{
${ }^{46}$ Ibid.

${ }^{47}$ Burbules and Warnick, "Philosophical Inquiry," 492-493; Further page citations in text.
} 
perform such analyses on ideas such as democracy, neoliberalism, and various schools of thought as relates to education. Through such inquiries, one can begin to see the assumptions made at a larger ideological level and then critique or support those assumptions as the case may be.

4. Philosophical inquiry sympathetically or critically reviews a specific argument offered elsewhere (pp. 494-495).

Burbules and Warnick describe this as the "prototypical" philosophical move (pp. 494). While not the sole purview of philosophical inquiry, this method lies at the core of most philosophical work. When properly operationalized, this philosophical tool allows one to analyze arguments for rhetorical tricks critically, used inadvertently or maliciously, that conceal or alter facets of the broader argument. Sometimes this can lead to excessively critical rhetorical arguments that may be less relevant to the broader discussion. That is not to suggest that there is no room for rhetorical techniques, but that an argument should not build its foundation solely upon them. Arguments that do not have honest, intellectual foundations will often be revealed through this form of analysis.

Especially in an age of "what works" thinking this method of analysis may appear trivial or overly concerned with semantics rather than substance. Burbules and Warnick, themselves, support this notion by saying that, "In a field of practice like education, where there is always a new challenge of the day, the luxury of such reflection and relentless questioning seems the privileged prerogative of the academic in the ivory tower" (pp. 494). However, they go on to highlight that with such critique what may at first appear to be a little assumption may have dramatic, perhaps catastrophic, consequences. The takeaway, then, is to embrace this natural tension. Excessive 
rhetorical critique can be paralyzing as those involved may never settle on a semantical point and thus be unwilling to move forward for fear of making a problematic assumption. However, decisions made without such considerations are open to abuse either by a politician seeking immediate political gain or by an outside party seeking to use education to serve their ends.

5. Philosophical inquiry questions a particular educational practice or policy (pp. 495-496).

While the previous methods are often the underpinnings of philosophical inquiry, this method is a common operationalization of one or several of the previous methods in education research. For example, education legislation may exist on logically shaky grounds or claim to expand college access generally but, once scrutinized, is revealed to only expand access for a particular demographic. My study relies on many such analyses such as Baez and Boyles' examination of SRE, which is done not through coding for specific keywords but through an analysis of the assumptions and philosophies that underpin that report. ${ }^{48}$ Burbules and Warnick would say that this method allowed Baez and Boyles to, "challenge the political motivations and agendas" behind SRE in a way that questions not solely the report, but the ethos that allowed SRE to be so. ${ }^{49}$

6. Philosophical inquiry proposes the ends or purposes education should achieve, either in terms of benefits to the person, to the society, or both (pp. 496-497).

\footnotetext{
${ }^{48}$ Baez and Boyles, The Politics of Inquiry, vii.

${ }^{49}$ Burbules and Warnick, "Philosophical Inquiry," 495; Further page citations in text.
} 
Like the previous method, this is less a standalone method and more of an aggregate of the previously described methods. However, unlike the previous method, this technique is often more constructive than critical. This method will be employed in this study to suggest the role universities should play in democratic governance. Burbules and Warnick suggest that methods such as the previous one allow for various perspectives to be less engaged with each other than they can be in this method (pp. 497). For example, one study may examine Title IX policies through feminist perspectives or the lens of a given theory of race, and that study need not necessarily consider the other perspective to be valid. However, when proposing the ends to which education should work it is prudent not to ignore these perspectives. That being said, it is difficult (if not impossible) to fully consider and acknowledge every perspective. This study, like others that propose such ends, does its best to consider a vast number of attitudes and values and seeks to satisfy as many of them as it can.

7. Philosophical inquiry speculates about alternative systems or practices of education that contrast with and challenge conventional educational understandings and practices (pp. 497-498).

Considered to be a challenging form of inquiry for the simple fact that it is often dismissed as irrelevant to the practicalities of the "real world." However, this form of philosophical inquiry is important because through it, "our current assumptions may come to seem less natural or neutral than we take them to be" (pp. 498). While this should never be the sole method of one's work, it is a useful tool on occasion to help push the boundaries of what is assumed to be possible. This method may ultimately suggest a possibility that is impossible to achieve, but that does not mean that scholars and 
practitioners alike ought not to work towards that impossibility, doing their best to approximate it as best they can in their work. Such thinking and spirit undergirds much of this study and provides some of the foundations for suggesting alternative means of policy and practice. Rather than calling for change for its own sake, the changes suggested in this study are put forth in the spirit of working toward an ideal.

8. Philosophical inquiry constitutes a thought experiment: A method that takes an imaginary situation, analyzes it, then gradually modifies one or another element of the situation to determine which features are relevant to changing its pertinent character (pp. 498).

Thought experiments can be invaluable tools for philosophers who seek to examine issues for which there is no existing example. It allows philosophers to ask "what if" questions and then examine the various aspects of that scenario and manipulate them at their leisure. This form of inquiry has a simple but important quality to it that cannot be overstated: it allows researchers to consider and examine possible scenarios that are potentially risky or harmful either to students or the institution. Questions such as, "What if classes had no teachers?" The question has merit and may be worth exploring, but the potential downfalls are too great for a school to create several classes without teachers and hope for the best. Even if the idea ultimately came to be adopted everywhere, it would inevitably require significant experimentation to get right, experimentation that is at the expense of the students who are in early versions of such classes. Any such change would come with a level of risk but thought experiments allow for philosophers to at least consider and offer critique on some aspects of the proposal 
and do their best to reduce or eliminate any harm or, if need be, scrap an idea altogether through uncovering an untenable flaw.

9. Philosophical inquiry constitutes an exegetical work: A close reading of a philosophical or literary text with an eye more toward explication and understanding of its complex meanings than analysis or critique (pp. 498-499). Often philosophers work with dense, perhaps oblique, texts. In such cases, it is useful for one researcher to read the text in question closely, possibly multiple times, and help uncover the meanings, or implied meanings, of what the original author was trying to say. Often this line of inquiry can serve to contextualize works in their broader historical context and help explain the various interpretations and applications of the text that have since occurred. What sets this method apart from the others is that it does not exist to offer criticism or support of a text so much as it seeks to explain it, allowing the reader to draw their own conclusions. It may not be entirely apolitical (if such a thing even exists), but more often than not such work tries to make a previous argument clearer, rather than offer a new argument.

10. Philosophical inquiry synthesizes disparate research from philosophy itself or other fields to find meanings and implications for educational theory and practice (pp. 499-500).

Central to this study and most work in philosophy of education is this final method. Education is so entangled with other disciplines that it is hard to imagine discussing it as separate or apart from them. ${ }^{50}$ The study contained in this thesis, in

\footnotetext{
${ }^{50}$ That is not to imply that researchers to do not attempt to do this. There can be a temptation to consider education policy in a vacuum, independent of larger societal forces. However, education is so central to policy considerations surrounding the economy, science and technology, and even that of war, that to
} 
particular, explores concepts relating to political science, economics, and moral education to name a few. As such, it is essential to synthesize research from these disciplines and illustrate their connection under the topic of higher education. The following chapter seeks to do this for the context of this study. ${ }^{51}$

While not an exhaustive list, these ten methods of philosophical inquiry were put forth as offering insight to non-philosophers about how philosophy of education might be conducted. These methods are often combined and layered to achieve a deeper understanding of the problem. ${ }^{52}$ They are designed to uncover the underlying logic behind an issue or to reveal the contradictions within an idea so that it may be better understood.

While this thesis uses several methods, it will use primarily three of the methods of inquiry listed above to frame this study. First, it synthesized historical analyses and research in education and political science to better understand the intersection between higher education and democracy (method \#10). Following a synthesis of the research, this study considered existing systems within higher education and analyzed how those

\footnotetext{
suggest it exists apart from the larger world is a fallacy at best. Burbules and Warnick view philosophy of education as an inherently interdisciplinary field and, as such, any philosophical research in education must by definition take other disciplines into account.

${ }^{51}$ It is worth noting that to synthesize the research of any one discipline entirely is nigh impossible. Consider the concept of democracy, for example. Countless books, articles, and reports have been written to explore this one idea within political theory, but it is far outside of the scope of this thesis to claim any exhaustive study of those texts. The intersectionality of this thesis further exacerbates this concern. Therefore, it was deemed prudent to select and review only those works most salient to the discussion at hand from each discipline in the hopes of offering a conclusion on the intersection of these ideas.

${ }^{52}$ Burbules and Warnick, "Philosophical Inquiry," 490.
} 
practices inhibit or reinforce democratic ideals (method \#5). Finally, this study offered suggestions on how universities may better promote and support democracy (method \#6).

\section{Data Sources}

The "data sources" in philosophical inquiry are often texts; that is, the critical analyses of texts form the basis for making claims about social phenomena. In this thesis, the "data sources" will consist of academic texts, articles, and theses/dissertations, which explicitly or implicitly link education (especially higher education) to democracy. Other sources of data will be government reports, reports commissioned through nongovernmental organizations, and reports that provide valuable statistical data for reference (e.g., the National Center for Education Statistics). Some sources used to guide the initial understanding of democracy include Democracy in America by Alexis de Tocqueville, The Phantom Public by Walter Lippmann, The Public and Its Problems by John Dewey, and Undoing the Demos by Wendy Brown. Other texts analyzed higher education and discussed its relation to democracy including Democracy and Education by John Dewey, The University in Ruins by Bill Readings, The Politics of Inquiry by Benjamin Baez and Deron Boyles, The Higher Learning in America by Thorstein Veblen, Neoliberalism's War on Higher Education by Henry Giroux, Distinction by Pierre Bourdieu, and Higher Education in America by Derek Bok. Multiversities, Ideas, and Democracy by George Fallis and The American College and University: A History by Frederick Rudolph provide thorough histories of the American university and serve as the primary sources for the historical perspective used in this thesis. 


\section{Summary}

This opening chapter outlined the topic for which the study in this thesis is designed to address. It highlights how neoliberalism has led to unfettered market-logic and the privatization of public institutions. As a result, democracy is facing a crisis in the U.S. as evidenced by the lack of trust placed in democratic institutions. This lack of trust is not limited to those in elected office but extends to those institutions which support American democracy, which includes the media and universities. As trust in public institutions is undermined private forces and entities can increase their influence and control. This thesis hopes to highlight the role universities have played in this privatization and the how that it is affecting universities as democratic institutions. Such illumination will hopefully lead to more thoughtful critique on higher education and democracy, including how these institutions rely upon one another. As this study concludes, it is incumbent upon universities to take a proactive role in reinvigorating democracy, and through a critique of those institutions, this study hopes to contribute to that conversation.

The rest of this thesis will be broken up into four chapters. The next chapter explores the concept of democracy and highlights what constitutes a healthy democracy. This chapter concludes with what democracy requires from its institutions of higher education, particularly universities, and a brief appraisal of how well universities have fulfilled this role throughout the past century. Chapter three takes a historical perspective and highlights how American colleges and universities have evolved. By adequately placing universities in their historical context this study hopes to make more apparent how and why universities became what they are today. Chapter four explores the modern 
corporate university and its current role. This chapter particularly highlights

neoliberalism and how it has affected universities. Chapter five concludes this study and answers the initial research questions. It ends by positing potential directions universities may take moving forward. 


\section{CHAPTER II}

\section{DEMOCRACY AND HIGHER EDUCATION}

This review aims to lay the historical and philosophical foundations for later discussions about the role of universities in democracy. It must first be noted that this thesis is engaging in several substantial and complex topics, any one of which could require a lifetime to engage with fully to understand the many nuances that have relevance to this discussion. As such, the goal of this study is to sample commonly referenced and influential texts from each area in the hopes of discovering salient ideas that illustrate fundamental connections between American democracy and universities. It is through these connections that a discussion will then occur on reasonable expectations and goals for universities and those interested parties concerned about the role of universities as democratic institutions. This chapter, in particular, is broken up into, broadly speaking, seven sections which hopefully build upon one another in laying the groundwork for the remainder of the study.

The first section articulates my understanding of democracy as a concept and seeks to contextualize democracy in an American context, borrowing heavily from the work of Alexis de Tocqueville, John Dewey, and Walter Lippmann. The next section engages more specifically with the idea of a "public" in a democracy, including what a public is and the role of a public in American democracy. Next, I will explore the qualities necessary for a healthy democracy and what American democracy, in particular, requires to function as it is intended. The remaining sections are a chronological look at how higher education evolved in the U.S. as it relates to being an institution of democracy. This part of the thesis is considered loosely in four sections: 1) Colonial 
America through the American Revolution; 2) $19^{\text {th }}$ century America through the Civil War; 3 ) the decades around the end of the $19^{\text {th }}$ and beginning of $20^{\text {th }}$ centuries; and 4) the bulk of the $20^{\text {th }}$ century until approximately the 1960 's. The historical analysis concludes here because the decades to follow and their changes to American universities are so essential to the discussion regarding what universities are today and the forces that influence them.

\section{American Democracy}

When discussing democracy, it is vital not to romanticize democracy to represent something that it does not. While collective rule has some meritorious features relative to other, more innately oppressive, systems of governing, democracy itself is not enough for a just society. This aspect was noted in the early days of American democracy by French political scientist Alexis de Tocqueville in his work, Democracy in America. ${ }^{53}$

Tocqueville was mostly an admirer of the attempt at democracy that the U.S. was making, and he sought to determine what facets of it he may bring back with him to a newly burgeoning French democracy. However, among his many poignant observations perhaps there is none more salient than his concern of the "tyranny of the majority.",54

In a democracy the majority rules by definition. Should that majority be working in a unified (or perhaps manipulated) direction then that majority can rule with a tyranny more oppressive than any monarch because the minority group has no recourse to affect

\footnotetext{
${ }^{53}$ Tocqueville, Democracy in America, 1-6.

${ }^{54}$ Ibid., 4.
} 
change, regardless of the knowledge or expertise they have. ${ }^{55}$ Tocqueville observed this phenomenon as a core facet stating, "The very essence of democratic government consists in the absolute sovereignty of the majority; for there is nothing in democratic states which is capable of resisting it. ${ }^{, 56}$ It is easy to see why democracy appealed to America's early founders who possessed so strong a spirit of freedom and liberty and who resented the English monarch who ruled them from across the sea.

However, by the time Alexis de Tocqueville traveled to the U.S. Andrew Jackson's populist democracy was well underway. This change permeated society including higher education where, for example, the residents of Schenectady, New York desired a college in their town rather than sending their children to the more established colleges in New York City. ${ }^{57}$ The General Counsel, who oversaw the creation of colleges, did not see the need for a college in Schenectady, but the people were not to be denied, and the college was built soon after. This college struggled like so many colleges in New York at that time did as they could not find enough students to fill them or enough money to fund their activities. ${ }^{58}$ As was the case in Schenectady, NY, tyranny is not always the tyranny of a vicious despot. The majority can be thoughtful or careless, cruel or compassionate, conservative or liberal. In either case, the majority is always legitimated through democracy as right. This absolute quality of democracy prompted Frederick

\footnotetext{
${ }^{55}$ Ibid., 124.

${ }^{56}$ Ibid.

${ }^{57}$ Rudolph, The American College and University: A History, 35.

${ }^{58}$ Ibid.
} 
Rudolph to comment that, "The institutions of the college movement in the U.S. intended to be, to the best of their ability and knowledge, democratic institutions for a democratic society. Necessarily, they reflected both the best and the worst of that society." 59

Tocqueville's commentary appears to hold up even when applied to the realworld forms of democracy that society adopts. A "pure" democracy, or "direct" democracy, is far too impractical as it would require every citizen to offer voice on every decision to be made, forcing citizens in Kentucky to weigh in the building of a road in Florida. Instead, the U.S. functions as a representative democracy with a complex system of local, state, and federal governing bodies all run according to their own constitutions which are ultimately answerable to the United States Constitution. ${ }^{60}$ So far as the government is concerned Americans elect representatives to do the work of government on their behalf in varying capacities. In such a democracy the majority does not rule directly, but its capacity for rule is still robust. Legislators are held to the will of the voting public, and with enough consensus, the majority can affect almost any change in our society.

However, let it not be stated that minority groups have no recourse in American democracy to advance their interests. The U.S. Constitution created a minority rule via the Electoral College, but even if the Electoral College does, in fact, enact the will of the

\footnotetext{
${ }^{59}$ Ibid., 67.

${ }^{60}$ Benjamin Baez, "Democracy," in Keywords in Youth Studies: Tracing Affects, Movement, Knowledges, ed. Nancy Lesko and Susan Talburt (New York, NY: Routledge, 2012), 153-157; For the sake of brevity, I will henceforth be referring to this particular form of democracy as manifested in America whenever I say "democracy" unless otherwise stated.
} 
majority once officials are elected, they have a certain autonomy from the public so long as they act under the rule of law. Furthermore, the practicalities of the U.S. make it such that financial backing often dictates the outcome of an election far more than a politician following the desires of their constituency. That backing rarely comes from the populace and usually reflects a few wealthy individuals funding politicians to curry favor with them to influence policy. Thus, it is possible for some minority groups to have disproportionate power in a democracy, but that requires disproportionate wealth or, at the very least, connections to powerful leaders.

Furthering this sentiment is Wendy Brown who posits that the majority, the demos, does not truly rule in a democracy. Brown states clearly, Never did the demos really rule in liberal democracies, nor could it in large nation-states. But the presumption that it should rule placed modest constraints on powerful would-be usurpers of its ghostly throne, helped to leash legislation aimed at benefiting the few, rather than the many, and episodically incited political action from below oriented toward the common concerns of ordinary lives. ${ }^{61}$

Brown's commentary drives at a core necessity of a healthy democracy, which is the trust that is placed upon those who are chosen to govern. For American democracy to function correctly, Americans must be able to trust its leaders to act in their best interests, including leaders in government, the economy, and in the local community. Therefore, it is incumbent upon the public to remain alert to the actions of those who lead and to exert

${ }^{61}$ Brown, Undoing the Demos, 207. 
its authority should the circumstances require change. The following section will explore this dynamic further by illustrating the nature of a public, its role in democracy, and critical facets to maintaining a healthy public in a democracy.

\section{The Public in a Democratic Society}

Before we continue, it is essential to explain what I mean in referring to the "public." A simple answer might be that the public is the collection of all members of society, but the realities are more nuanced than that. With today's globalization, it can be argued that everybody on Earth is a member of a global society and thus all a part of the public. However, what if one refers to American society? Does that public become limited to those who live in the U.S. at the time? Does this include visitors from other nations or only those with full citizenship? When scaled down even further, does a woman from Los Angeles belong to the South Florida public? All of these questions necessitate more subtlety of thought and a finer understanding of what it means to be in a public.

For Jürgen Habermas, the public was a concept reserved for the bourgeois. Private individuals would come together in "public spheres" to share their ideas and concerns and then use their power and influence on the formal institutes of government. ${ }^{62}$ However, Nancy Fraser tells us that for Habermas the public sphere, "is conceptually distinct from the state; it a site for the production and circulation of discourses that can in principle be

\footnotetext{
${ }^{62}$ Jürgen Habermas, The Structural Transformation of the Public Sphere: An Inquiry into a Category of Bourgeois Society, trans. Thomas Burger (Cambridge, MA: Massachusetts Institute of Technology, 2000).
} 
critical of the state. ${ }^{, 63}$ Fraser went on to say that Habermas' conceptualization of the public was distinct from market relations as well. It was a sphere of and for discursive relations. This idea of the public allows for the separation of the state, the market, and other entities related to democratic theory.

On the other hand, political science is less precise in its use of the term, and so it may change in exact meaning with each new theory or book. Generally, in political science "the public" refers to the populace in a society. The collective will and desires of the public are the "public interest." However, Clarke Cochran critiqued this notion saying, "There can be no public interest because there is no public or community other than the aggregation of individuals and special interest groups which they form." ${ }^{64}$ Cochran argues that there is no "public interest" toward a "common good" and so we are left with these nebulous collections of individuals acting as "publics" for their own gain.

For this thesis, I will follow Dewey's articulation that a public consists of an association of individuals brought together by a shared interest, be that interest in religion, scientific inquiry, or a commonality as similar members of an oppressed group ${ }^{65}$ However, according to Dewey that alone was not enough to constitute a public. A public is called into being by the consequences of the actions by an external actor. As Dewey stated,

\footnotetext{
${ }^{63}$ Nancy Fraser, "Rethinking the Public Sphere: A Contribution to the Critique of Actually Existing Democracy," Social Text, no. 25/26 (1990): 56-80.

${ }^{64}$ Clarke E. Cochran, "Political Science and 'The Public Interest'," The Journal of Politics 36, no. 2 (May 1974): 327-355.

${ }^{65}$ Dewey, The Public and its Problems, 28-29.
} 
...when a family connection, a church, a trade union, a business corporation, or an educational institution conducts itself so as to affect large numbers outside of itself, those who are affected form a public which endeavors to act through suitable structures, and thus to organize itself for oversight and regulation. ${ }^{66}$ This public is recognized externally through the existence of officials who represent the interests of that public. In this way, there are numerous publics, and those publics may come into existence as is necessary or break apart once the reason for their origin is resolved. It is not inaccurate to say that members of government in a democracy are the officials created by the public which elected them. However, among that public may be another public that forms because of the policies enacted by the government. This new public creates officials of its own to address the issues created by the government of the state.

While Dewey helps us understand what a public is, an exploration of the role of that public will be further aided by Walter Lippmann, a contemporary of John Dewey. Lippmann wrote at length about the issues facing democracy and American society during the early $20^{\text {th }}$ century, and though there may have been tension between his conceptualizations of democracy and Dewey's, there remained a few areas of agreement between them regarding what democracy asks of the common citizen. Lippmann discussed what he called "the unattainable ideal" of the omnicompetent citizen. ${ }^{67}$ Lippmann argued that the theory of democracy requires its citizens to be omnicompetent,

\footnotetext{
${ }^{66}$ Ibid., 28-29.

${ }^{67}$ Lippmann, The Phantom Public, 29.
} 
to have at least proficient knowledge on virtually all topics so that they, as the governors in a democracy, could rule effectively. The average citizen was expected under this ideal to be equally knowledgeable in matters of state, war, and commerce as they were their personal affairs. Not only is this "unattainable" but it is an unreasonable goal for society to work towards. While a more educated populace is preferred in a democracy, it is unrealistic that average members of society could be sufficiently educated on complex issues, such as the Israeli-Palestine conflict, to be able to write policy that affects those matters. So, if the public does not play this role then what role do they serve in a democracy?

Lippmann suggested that the chief role of a citizen in American democracy was as a voting citizen. ${ }^{68}$ This view perhaps overly simplifies the larger role citizens may play in a democratic society (through protests, grassroots campaigns, and other methods of civic and community engagement), but it is nevertheless among the most direct means of governance available to citizens in a democracy. Lippmann likened elections to war without physical violence and said voting is, "an act of enlistment, an alignment for or against, a mobilization." ${ }^{\circ 9}$ The majority wins this "war" in democracy and so, in keeping with de Tocqueville, is the tyranny of the majority legitimated through the mechanisms of democracy. As for the public, by casting a ballot they are not offering their views on specific policy but showing their support for one candidate over another. In most

\footnotetext{
${ }^{68}$ Ibid., 45.

${ }^{69}$ Ibid., 48.
} 
elections, the choice is between two or three candidates and voters declare their support for one over the other.

The public's primary role from this point of view is as a voter, and their primary form of influence is by supporting one candidate over another. However, the public is still acted upon and forced to live by policies enacted by those elected officials.

Lippmann referred to these as "rules" and argued that the majority of rules that we live by are of little to no concern in that we are not bothered by their existence. ${ }^{70}$ In the U.S. we accept that you are supposed to drive on the right side of the road, whereas in England or Japan you drive on the left side of the road. This rule is pretty significant when it comes to the construction of infrastructure and how cars are designed, but ultimately the public is untroubled by the decision either way and feels no compulsion to change the rule. On the other hand, some rules are of concern to the public, rules that Lippmann considered 'failures. ${ }^{71}$ Failures may have been agreed upon and supported at the time but were ultimately found to be problematic. The prohibition of alcohol was supported in the U.S. resulting in a constitutional amendment, but this rule was later repealed because the public too deeply questioned its validity.

While the public may act through elected officials, it is ultimately the public who is responsible for offering this judgment. Lippmann put two questions before the public for which they are responsible for answering as the need arose: "First, is the rule defective? Second, how shall the agency be recognized which is most likely to mend

\footnotetext{
${ }^{70}$ Ibid., 105.

${ }^{71}$ Ibid.
} 
it?"72 The public is to answer these questions in part through the use of public debates where particularly knowledgeable individuals discuss the rule in question. These debates are less about educating the public and more about making more transparent the interests behind a rule. ${ }^{73}$ Through a proper public discussion, the public more clearly sees the interests of the advocate and the detractor. Those speaking in self-interest are revealed to be doing so, and the public now can act on that information as they see fit. As in an election, this manner of discourse becomes members of the public offering their support for one side over the other or one individual over another. Lippmann then offers criteria for how to reform a rule, and while the details of that process are less relevant to this discussion let it be stated that the public plays a similar role in ensuring the new or reformed version of the rule is valid. ${ }^{74}$

Of course, it is easy to suggest that whenever an issue arises that a public need only to form together and mobilize against it. However, anybody involved in community organization can attest that the matter is not as straightforward as that. Publics are not premade entities ready to be deployed, but instead, they must be formulated each time for the cause. Nearly a century ago Dewey described some of the difficulties in forming a public saying, "There are too many publics and too much of public concern for our

\footnotetext{
${ }^{72}$ Ibid., 98.

${ }^{73}$ Ibid., 100-104.

${ }^{74}$ Ibid., 115-133.
} 
existing resources to cope with. The problem of a democratically organized public is primarily and essentially an intellectual problem.",75

Dewey was speaking during the period between World War I and World War II where the economy was reeling and so many publics needed the support of the larger society, but the central question remains relevant today. The scope and scale of the issues facing the various publics in the U.S. today require a significant amount of coordination and consistency of purpose that is difficult to acquire in any era. Furthermore, as I will explore later in this thesis, there is a dampening effort being applied to the very idea of a public through intense efforts at privatizing all aspects of society. Though the circumstances may differ Dewey's commentary remains salient today that, An inchoate public is capable of organization only when indirect consequences are perceived, and when it is possible to project agencies which order their occurrence. At present, many consequences are felt rather than perceived; they are suffered, but they cannot be said to be known, for they are not, by those who experience them, referred to their origins. ${ }^{76}$

Dewey goes on to conclude that due to this lack of perception of the root issue that systems are not established to address them. Instead, such "publics are amorphous and unarticulated.,"77

\footnotetext{
${ }^{75}$ Dewey, The Public and its Problems, 126.

${ }^{76}$ Ibid., 131.

${ }^{77}$ Ibid.
} 
To conclude, the public must not only elect and offer critique on the actions of officials, but it must also see to activating and cultivating itself as a public. This final point is perhaps the most crucial and possibly the most difficult to achieve. For a public to be effective, it must first realize itself as a unified public, understand the source of the issue that forced the public into existence, and then create a plan for remedying the issue through the influence of its officials. Dewey described it as essentially an intellectual problem and so intellectual development that will likely be the solution. While this section explored the role of the public, the next section examines more generally what is required for a healthy democracy to survive. What follows is by no means an exhaustive list, but it will hopefully offer a useful perspective moving forward.

\section{The Needs of Democracy}

This discussion will pick up at what I believe was a crucial moment in American history where the country set the course that defined what American democracy was meant to be and that, despite undergoing numerous changes and ideologies, remains at the fore today. As World War II came to a close, the U.S. sought to ensure that it did not repeat its mistakes that led to the Great Depression. After the First World War, the U.S. enjoyed an economic boom that ultimately crashed with its stock market. The economic devastation left thousands of Americans homeless, jobless, and with nowhere to turn to aid. World War II provided a reprieve as many found work in joining the military, citizens with money purchased war bonds to supplement the government, and the industry of war presented a source of jobs and income for those back home who fed the military machine that fought throughout Europe. 
The question became what to do to prevent such a catastrophe again, and the answer was the emergence of the welfare state. ${ }^{78}$ This term describes the "social contract" between citizens and government in their capitalist market economy. The role of the government was greatly expanded and was tasked with ensuring the well-being of the public. Previously, the welfare of an individual was primarily left up to the market economy and the advantages afforded by social class. While democracy does not equate to capitalism, or vice versa, under the welfare state, the two become inextricably linked together, for better or worse. ${ }^{79}$ Under this system, the needs of the market are related to the needs of democracy, and while those needs are not exactly one to one, they are connected strongly enough so that they cannot be considered independently anymore.

In describing the welfare state, Fallis outlines core facets necessary for the welfare state to succeed. ${ }^{80}$ While by no means an exhaustive list, this outline does serve to provide a good perspective on what is generally required for the welfare state to stay healthy and, by extension, what modern democracy requires as well. Fallis describes the following as the four intellectual pillars of the welfare state:

1. Government policies dealing with unemployment;

2. Government social insurance and social expenditures;

3. The concept of social citizenship;

\footnotetext{
${ }^{78}$ Fallis, Multiversities, Ideas, and Democracy, 85.

${ }^{79}$ Ibid., 84-85.

${ }^{80}$ Ibid., 88.
} 
4. The system of progressive taxation to finance the welfare state. ${ }^{81}$

Below I will explore each of these ideas in more detail as relates specifically to democracy.

\section{Reducing the Level of Unemployment}

As described previously, democracy requires that members of the populace have the means to be engaged as a public when it becomes necessary for them to do so. Practically speaking, being engaged requires certain things that are not guaranteed as a right. Forming together as a public in $21^{\text {st }}$ century America, for most people, means having reliable internet access. In most states, voting requires the means to transport oneself to the correct polling place. Attending mass protests, a familiar sight and useful tool for expressing displeasure with society, requires the funds and resources to actually get to the protest location, participate for as long as the protest lasts (perhaps involving hotel and other costs), and the means to return home. These and so many other factors of democratic engagement require the funds and resources for the masses that can only be provided by mass employment.

Though exceptions exist, the vast majority of Americans require having a job to not only cover necessities like food and shelter but to have the means to be engaged, democratic citizens. Borrowing from the ideas of John Maynard Keynes, Fallis offered that, "The bedrock for the well-being of a citizen is to have a job." ${ }^{82} \mathrm{~A}$ job is so crucial to have the lifestyle that affords one the opportunity to be engaged that the government has

\footnotetext{
${ }^{81}$ Ibid., 88.

${ }^{82}$ Ibid., 87.
} 
a responsibility to create policy and legislation that reduces unemployment. The extent of this responsibility (guaranteed income for all as one example) and the method to achieve it may be subject to debate, but it is generally accepted now that the government has a significant role to play in ensuring employment opportunities for the masses.

\section{Social Insurance and Social Expenditures}

While government seeks to ensure gainful employment for the populace, it must also understand that this is not always possible, and it is during these cases where the government must have redundancies in place to compensate for when market capitalism

does not work for everybody. ${ }^{83}$ Whether it be due to retirement, illness, or unemployment resulting from a factory closing, the government is responsible for providing insurances to these people so that they may still have the opportunity to be democratically engaged.

\section{Social Citizenship}

Pulling from the work of Thomas Marshall, social citizenship refers to the kind of citizenship necessary for the welfare state. ${ }^{84}$ This kind of citizenship is understood as individuals having the rights necessary for individual freedom and the rights required to exercise political power; it is also the responsibility of the citizen to live according to the standards of society. Such citizenship creates a tension between society's need to socialize an individual to society's norms and an individual or group's right to differences. Education is often a significant factor with regards to this facet of social citizenship and comes into play on both fronts. Generally, education systems act as

\footnotetext{
${ }^{83}$ Ibid., 100-102.

${ }^{84}$ Ibid., 102-103.
} 
agents of socialization (I explore this in more detail later), but education also provides expanded opportunities for one to assert their rights, liberty, and political power. There is no clear path forward that resolves this tension, and it is the responsibility of the welfare state to manage it without ever committing the fallacy of declaring the issue resolved.

\section{Progressive Taxation to Finance the Welfare State}

The fiscal needs of the welfare state are significant, so extensive taxation is all but required in a system that relies on government intervention to address society's ills. ${ }^{85} \mathrm{~A}$ key but implicit point underlying this pillar of the welfare state is that the government must be concerned with reducing wealth and income inequality among its citizens. ${ }^{86}$ Full equality is not necessary, but when wealth is too concentrated, it becomes impossible for there to be equality in terms of democratic engagement. It is perhaps this pillar where the U.S. has suffered the most failures as a nation and does not currently appear to be doing any better. Wealth is increasingly concentrated among the very rich and the 2010 ruling by the Supreme Court of the United States in Citizens United only furthers the ability for the extremely wealthy to exert disproportionate levels of political power. ${ }^{87}$ By slowing or even reducing this level of inequality government could potentially provide far greater opportunity for the masses to play their part in democracy, and there have been some positive indicators that support this. The 2016 presidential campaign by Bernie Sanders demonstrated how large numbers of people offering modest financial support can still

\footnotetext{
${ }^{85}$ Fallis, Multiversities, Ideas, and Democracy, 103-104.

${ }^{86}$ Ibid.

${ }^{87}$ Lafer, "The Corporate Assault on Higher Education."
} 
influence the political scene, but such occurrences are rare and difficult to be duplicated. On the other hand, the formula of a few wealthy individuals exerting their power to have disproportionate influence is well documented. ${ }^{88}$

The needs of democracy are nuanced and difficult to explore fully, but this outline provides a useful guide moving forward as I examine the role education and universities have played and will play in American democracy. Brown offers us another cogent perspective when she says "In short, the essential conditions of democratic existence remain these: limited extremes of concentrated wealth and poverty, orientation toward citizenship as a practice of considering the public good, and citizens modestly discerning about the ways of power, history, representation, and justice." 89

\section{Summary}

The previous sections spoke to the needs of democracy and help us answer what role universities play in American democracy. Chapter four will highlight the specific issues facing democracy today, but before those issues are addressed, it is necessary to historicize universities and their role in American democracy until now. This is what chapter three hopes to do. First, I will explore the early days of higher education in the U.S. through the $19^{\text {th }}$ century, including influences from other college and university systems during that time that ultimately made their way into the American college and university scene. ${ }^{90}$ Second, I will discuss the decades surrounding the end of the $19^{\text {th }}$

\footnotetext{
${ }^{88}$ Ibid.

${ }^{89}$ Brown, Undoing the Demos, 179.

${ }^{90}$ The bulk of my historical understandings of American higher education come from Frederick Rudolph's work, The American College \& University: A History. Initially published in 1962, Rudolph thoroughly
} 
century and the beginning of the $20^{\text {th }}$ as this era saw significant changes in American society that left a lasting impact on higher education including the advent of land-grant colleges and the more widespread inclusion of women and non-whites. The third section will chart the bulk of the $20^{\text {th }}$ century with particular emphasis on the post-World War II era and the role of universities in the welfare state detailed previously. The subsequent chapter will discuss the end of the $20^{\text {th }}$ century to present with the rise of the corporate university and where higher education appears to be going.

explores the practices, influences, and context of American colleges from the founding of Harvard through the early decades of the $20^{\text {th }}$ century. Rudolph regularly cites historical documents and speeches made by the influential members of that era. 


\section{CHAPTER III}

\section{THE EARLY DAYS OF AMERICAN HIGHER EDUCATION}

The beginning of higher education in the new colony was not built upon some grand ideal of democracy, equality, or even the pursuit of knowledge and some higher truth. Instead, Harvard College was founded on October $28^{\text {th }}, 1636$ in Cambridge, Massachusetts for broadly two reasons. ${ }^{91}$ First, as the name of the town might imply, English settlers who attended Oxford and Cambridge before traveling across the ocean were nostalgic for home and wanted to bring a piece of that home into these unfamiliar lands. Second, and perhaps more significantly, there was a shared sentiment that it was time for the colonies to start training its leaders instead of importing them from the educated elite in England. A proper colony required, "competent rulers, the church would require a learned clergy, and society itself would need the adornment of cultured men."92 First came Harvard but eventually several colonial colleges came into being all primarily designed to train three types of individuals: leaders with knowledge enough to rule, clergy trained in leading their respective churches, and men who were seen as refined and cultured through classical English schooling. ${ }^{93}$ In short, early higher education in the U.S. was created by and for the elite.

\footnotetext{
${ }^{91}$ Rudolph, The American College and University: A History, 3.

${ }^{92}$ Ibid., 6.

${ }^{93}$ Ibid., 13.
} 
Daniel Bennett discusses how these early colleges gained their footing primarily due to the contributions by the legislature. ${ }^{94}$ Between large public grants, taxes levied, and toll stations early colleges, even those we consider to be private institutions, received a majority of their funding from the legislature. More than half of Harvard's income came from government subsidies and, "less than 10 percent was derived from tuition." ${ }^{95}$ Other colleges received similar benefits including Yale University and William and Mary. Though they varied perhaps in frequency and the size of the gifts all of the colonial colleges were able to get their start through sizeable public funding and large gifts in the form of land, money, and exemptions from many taxes. Not only did this give early colleges the boost they needed to survive, but it also created a monopolistic atmosphere where these colleges would see no real competition. ${ }^{96}$

Early American colleges mostly followed the English tradition of residential colleges. ${ }^{97}$ These were small remote colleges that emphasized cultivating character and morality at least as much as they were concerned with knowledge for knowledge's sake. American colonial colleges shared a similar educational legacy with Cardinal John Henry Newman who felt that a liberal education preparing the student for life in government or the clergy was the real aim of higher education and held a rather scornful view of

\footnotetext{
${ }^{94}$ David L. Bennett, "Myth Busting: The Laissez-Faire Origins of American Higher Education," Independent Review 18, no. 4 (Spring 2014), 503-525.

${ }^{95}$ Ibid., 509.

${ }^{96}$ Ibid., 507-510.

${ }^{97}$ Rudolph, The American College and University: A History, 3-5.
} 
teaching "useful knowledge." $" 98$ American colleges emphasized a curriculum based on the classics and made mandatory that all of the young boys who attended took an active role in the religious proceedings. ${ }^{99}$

Classical education dominated the way of thinking in higher education through the early $19^{\text {th }}$ century, but as the U.S. colonized the frontier so too did colleges move west. Coupling the interests of more learned individuals and churches wanting their denomination to be represented in each state the number of colleges skyrocketed during this time. ${ }^{100}$ After the American Revolution there were nine colleges, but in the following years, as many as 700 colleges were founded with around 250 existing during the time of the Civil War with 182 still existing today. ${ }^{101}$ During this time the idea of what American colleges began to change. The American college was still seen as a social investment, but, "for all its European origins, was expected to be democratic."102 A subtle shift was occurring colleges were being charged with looking toward the needs of society and not solely the elite who were the primary attendees. Jacksonian democracy ushered in an era where the populace was no longer willing to support institutions that only served the

${ }^{98}$ Clark Kerr, The Uses of the University, $5^{\text {th }}$ ed. (Cambridge, MA: Harvard University Press, 2001); John Henry Newman, The Idea of a University, ed. Frank M. Turner (Binghampton, NY: Vail-Ballou Press, 1996).

${ }^{99}$ Rudolph, The American College and University: A History, 4.

${ }^{100}$ Ibid., 47.

101 Ibid.

102 Ibid., 63. 
elite, so many colleges were pressured to appeal to a relatively larger percentage of the population. ${ }^{103}$

\section{Higher Education in the Late $19^{\text {th }}$ and Early $20^{\text {th }}$ Century}

Whatever the early days of American higher education were, by the end of the $19^{\text {th }}$ century American colleges were becoming more democratic institutions. Students became increasingly interested in dictating the kind of education they received, and many were not interested in strictly classical education. Enlightenment ideals were on the rise and students wanted an education around practical subjects like science and mathematics. Initially, colleges were steadfast in their unwillingness to alter the curriculum thus leading to the formation of literary societies. ${ }^{104}$ These societies were student-run organizations and often featured an entire "extracurriculum" focusing on subjects absent from traditional schoolings such as science and modern literature. Much to the chagrin of college officials, students would invite controversial intellectuals to campus to give lectures. The students at Williams College invited Ralph Waldo Emerson on three occasions and all three times were denied the use of school buildings and facilities despite the distinction Emerson had even in his day. ${ }^{105}$

Eventually, these literary societies won out and what was the extracurriculum came to be a part of college curriculum. Thomas Jefferson at University of Virginia and a few others of the early $19^{\text {th }}$ century made attempts to incorporate a more elective

\footnotetext{
${ }^{103}$ Ibid., 201-220.

${ }^{104}$ Ibid., 137.

${ }^{105}$ Ibid., 142.
} 
curriculum with diverse faculty bodies and grant students more freedom to pursue their particular interest. ${ }^{106}$ Those efforts mostly failed due to a lack of students to fund a large enough faculty to make such a structure tenable, but by the end of the Civil War, colleges were seeing their attendance numbers rise despite the massive increase in the number of colleges. In 1869 Harvard College selected Charles Eliot to be its new president, and he felt that the time had come for colleges to abandon the prescribed classical education in favor of an elective curriculum featuring more "practical" subjects. ${ }^{107}$ The movement towards elective education as the standard was not only a means to incorporate science, modern literature, and technology studies but also a result of decades of American populist sentiment that sought to empower the masses instead of the elite. In this case the students instead of faculty and school governing boards.

Significant federal legislation in the form of the Morrill Land-Grant Acts aided this rise in the number of colleges and the number of students attending those colleges. The Morrill Land-Grant Act of 1862 rejected previous notions of college mission and purpose by substantially investing in the creation and support of agriculture based colleges. ${ }^{108}$ These colleges would be public colleges run by the state with initial funds coming from large federal grants. Their purpose was to provide technological and agricultural education and innovations to serve the needs of the American frontier as it expanded west. States would be given land and money to create these colleges and were

\footnotetext{
${ }^{106}$ Ibid., 125.

${ }^{107}$ Ibid., 290-291.

${ }^{108}$ Ibid., 247-252; Morrill-Land Grant Act of 1862.
} 
tasked with ensuring they provided educational services that more immediately impacted the lives of their surrounding communities.

Communities became very interested in these new colleges that were perceived as having more "practical" value for the community and thus worthy of more investment, and by 1955 land-grant colleges came to account for $20 \%$ of the enrolled student population. ${ }^{109}$ Colleges were becoming more democratic institutions in that they enrolled students from a broader population than before and were more directly serving the needs of the community. This ideal was extended further by the second Morrill Land-Grant Act of 1890 , which prohibited funds to schools that denied admission based on race. ${ }^{110}$ Unable to force colleges to enroll students of all ethnicities, federal funds were instead used as leverage to pressure colleges to adopt such policies. ${ }^{111}$ By no means a curative, this at least marked significant efforts towards addressing some of the inequalities in the U.S. and the role of colleges in those efforts.

These changes in curriculum and student body gave rise to another fundamental shift in higher education. As more public funds were being given over to colleges, it was felt that college standards needed to be improved. ${ }^{112}$ Where most colleges had previously tended to the moral and cultural development of their students, by the close of the $19^{\text {th }}$ -

\footnotetext{
${ }^{109}$ Rudolph, The American College and University: A History, 244.

${ }^{110}$ Morrill Land-Grant Act of 1890.

${ }^{111}$ Future rulings in the United States Supreme Court demonstrate the tenuous nature of such policies. Many are easily challenged in court while other policies have been upheld. Generally, race can only be a considered factor in admissions practices.

${ }^{112}$ Rudolph, The American College and University: A History, 280-282.
} 
century colleges became more focused on scholarly pursuits, including the pursuit of truth and knowledge such as it was understood at the time. Many college professors were increasingly being trained in German universities, and it was felt that the U.S. needed universities of its own to train its scholars and engage in research. ${ }^{113}$ In 1876 John Hopkins University became the first graduate school in the U.S. based on the German model. ${ }^{114}$ The vast majority of colleges that became universities did not abandon their original purpose of educating the masses or tending to the needs of the local community. In fact, aside from the business of training more scholars who would teach at universities, graduate schools were primarily dedicated to research for the community. ${ }^{115}$

As colleges endeavored to increase the standards of their scholarship, there was growing concern that colleges would no longer serve the wider population that they were beginning to accept. Colleges had more rigorous admission standards, and the meager amounts of remedial education offered through preparatory departments were not enough to fill the educational gap many students had going from primary to higher education. ${ }^{116}$ The state of Michigan offered the solution that has now become universal in the U.S. in the form of creating public high schools. Beginning in 1870, Michigan created high schools to bridge primary and higher education allowing colleges to increase their admission standards without becoming the sole purview of the wealthy elite, the only

\footnotetext{
${ }^{113}$ Ibid., 268-269.

${ }^{114}$ Ibid., 269.

${ }^{115}$ Ibid., 268-270.

${ }^{116}$ Ibid., 280-282.
} 
class that could reasonably afford to educate their children to meet these new higher standards sufficiently. ${ }^{117}$ As a public and free institution, high schools made, "the American college a democratic institution" by becoming the primary means to get to college. ${ }^{118}$ As this system spread to other states, the groundwork was laid for the massification of higher education that would come in the following century. Over time, colleges and universities offered a credential for most professions and replaced the apprenticeship system. In disrupting these often exclusive networks, universities became the primary site to be trained for a profession while admitting significantly more people from historically underrepresented, if not outright excluded, demographics.

With these increases in access to education, schools came to be viewed as having a purpose and responsibility to democracy. Historically, colleges served the elite and only influenced democracy inasmuch as the leaders tended to be college educated, but as more people enrolled in schools became more thoughtful about socializing their students to be democratic citizens. Among the more influential texts in this regard was Dewey which argued that directed education should result in graduates who had the intellectual freedom and capacity to shape the world around them. ${ }^{119}$ The means to achieve such an education required a rethinking of the educational landscape to include more collaborative learning and group work as well as a liberal and vocational education. ${ }^{120}$ Learning, in Dewey's

${ }^{117}$ Ibid., 283.

${ }^{118}$ Ibid., 284.

119 John Dewey, Democracy and Education, (New York, NY: The Free Press, 1997), 10-22.

${ }^{120}$ Ibid., 100-110. 
opinion, ought to emphasize growth and experience as opposed to the recitation of facts or literature. This perspective is reflected in a later scholar's observation that, "adjustments to individual capacities should be made by permitting the student to proceed at his own pace, taking the examinations when in his opinion he is ready to take them."121 While not all of Dewey's ideas came to fruition, they do form the basis for how many view schooling to serve both the individual and a larger societal purpose.

\section{Corporatization of Higher Education}

The influence of private funds and other corporate influences on colleges and universities is a subject I will revisit in more detail later, but it is worth noting the concern around this topic that existed by the beginning of the $20^{\text {th }}$ century. While modern critics of these phenomena often cite the growing influence of neoliberalism and marketideology, early $20^{\text {th }}$ century scholars shared many of the same concerns, though they did not yet use the words that we have today. ${ }^{122}$ Among the more prominent of these commentators was Thorstein Veblen whose original work was published in 1918. Veblen built upon decades of already existing literature critiquing the corporatization of higher education, and of particular concern to Veblen was how that corporatization would inhibit the "disinterested pursuit of knowledge." ${ }^{123}$ As many scholars of the day, Veblen saw this pursuit of knowledge and truth as the most important task of higher education

\footnotetext{
${ }^{121}$ Robert Maynard Hutchins, The Higher Learning in America, (New Haven, CT: Yale University Press, 1936), 19.

${ }^{122}$ Veblen, The Higher Learning in America, 10.

${ }^{123}$ Ibid., 38.
} 
and that there was no reason for inhibiting it, for to do so was to inhibit society as a whole. Somewhat a pragmatist, however, Veblen understood the practical nature of colleges and universities and their need to, "serve the dominant social order and yet continue to serve ideals and maintain practices that keep it apart from that order." 124 Navigating and managing this tension was of high importance and necessary to the ongoing work of education.

Hutchins' echoed many of these concerns about the corporatization of higher education. ${ }^{125}$ His most significant concern was of the amount of money flowing into colleges and universities and the love that these institutions had of money. It was not solely private funds and donations that concern Hutchins but all money that came with stipulations. Hutchins was almost equally concerned about the ever-increasing role of the state in college and university work, a result in part of the ever-increasing public dollars provided by the state. ${ }^{126}$ In his view, universities needed to be more self-sufficient in their finances to maintain the independence and autonomy that he felt they needed. Any funds given, be they from a corporate partner or a state legislator, came with stipulations that granted control and authority over an institution.

However, others still maintained such obligations were a necessity, distasteful or not. John Hardin Best summarizes how the president of Stanford University at the beginning of the $20^{\text {th }}$ century, David Starr Jordan, "decided to lay aside the principle of

\footnotetext{
${ }^{124}$ Ibid., 29.

${ }^{125}$ Hutchins, The Higher Learning in America, 35.

${ }^{126}$ Ibid., 33-58.
} 
academic freedom in the face of the vagaries of the university's great benefactor."127 Academic, intellectual, and social values were seen as valuable to universities, but they were not to come into conflict with the university's endowment. Such things are "screened through the policy machinery of any institution with always the essential question: what are the implications for the institution's position in the competitive market, what fiscal consequences in the long and short term follow, in sum, what is the effect on the 'ship'?" 128 It was such concerns that lend validity to Hutchins' concern with the "love of money" that universities seem to hold.

Like other scholars of his era, Hutchins was concerned about general education and its role at the university. ${ }^{129}$ In his view, general education should be geared towards the cultivation of intellect and less concerned about the utility of the knowledge, and that utility only had a place in a student's major of study, but even this view appeared to rankle Hutchins to some degree. While he did not wish to do away with professional education, he felt that those fields were gaining too much influence over the university and warned against the creeping power of law schools, medical schools, and other professional programs that he felt, at best, only warranted limited space at the university. ${ }^{130}$ To that end, Hutchins felt that the very idea of the university was

\footnotetext{
${ }^{127}$ John Hardin Best, "The Revolution of Markets and Management: Toward a History of American Higher Education since 1945," History of Education Quarterly 28, no. 2 (Summer 1988), 180.

${ }^{128}$ Ibid.

${ }^{129}$ Hutchins, The Higher Learning in America, 59-87.

${ }^{130}$ Ibid., 51.
} 
problematic for higher education. Graduate schools and graduate research "confused" the purpose of the university distracting it from the work of educating undergraduates. ${ }^{131}$ Though the two entities could coexist in one school, that existence would always be fraught with tension as the two missions are, in his mind, fundamentally different.

\section{Higher Education in the $20^{\text {th }}$ Century}

The $20^{\text {th }}$ century marked a period of unprecedented growth and expansion in American higher education. Where the $19^{\text {th }}$ century saw the creation of hundreds of staterun colleges and universities, the following century endeavored to create hundreds and then thousands more and to expand significantly the number of people attending those institutions. In this section, I will outline some of that changing dynamic as universities came to be viewed as institutions of the state to address state issues. This new role included educating the masses to rapidly changing industries and economies, conducting research that would be used to support state policies and actions, and tend to the intellectual cultivation of massive swathes of society. Many changes to university life were intentional, but they came with unexpected consequences. These include professors carving out expansive rights and freedoms to conduct their work free from interference from college administrations or the state, or students finding an agency and voice within university spaces and using that platform to establish themselves as more equal actors alongside governing boards, politicians, professors, and college presidents.

\footnotetext{
${ }^{131}$ Ibid., 4.
} 


\section{The Wisconsin Idea}

While not the only state to engage in such efforts, the University of Wisconsin and the state created strong ties early on which helped bolster the university into a national powerhouse. ${ }^{132}$ Called the Wisconsin Idea, this alliance between university and state allowed university officials to lead many of the new regulatory commissions as well as leverage university research to address state issues. The idea was founded on the belief that democracy would work better if intellectual thought and reason addressed the problems of society. The University of Wisconsin did more than crafting behind-thescenes legislation, however. It also pursued initiatives that directly impacted its community in the form of extension courses designed to bring the work of the university to the community at large. ${ }^{133}$ Wisconsin was not the only state to have such policies and partnerships, but they were leaders in this progressive spirit and created patterns emulated throughout the country that all worked to make universities more democratic.

\section{The GI Bill}

While states such as Wisconsin utilized universities towards progressive ends, the federal government levied its resources primarily to assist World War II veterans returning after the war. Most prominent among these legislative efforts was the G.I. Bill of 1944, which provided billions of dollars in tuition assistance, housing loans, and other support services for military veterans. ${ }^{134}$ Though college enrollments were rising

\footnotetext{
${ }^{132}$ Rudolph, The American College and University: A History, 483.

${ }^{133}$ Ibid., 362-363.

${ }^{134}$ Ibid., 483-484.
} 
somewhat before World War II, it was due to these dramatic shifts in focus and policy that university enrollments ballooned. ${ }^{135}$ In 1870 , only $1.7 \%$ of $18-21$-year-old Americans were enrolled in a college or university, but by 1970 that same demographic saw approximately half of its cohort in higher education. ${ }^{136}$ This era signified the "massification of higher education" by breaking down some of the class barriers in the U.S. unlike any educational institution before it. ${ }^{137}$ The G.I. Bill was an integral piece of a broader movement in American policy towards more equitable institutions for all in the name of a stronger democracy.

However, despite the overwhelming success of this bill and similar legislation of the time (such as Roosevelt's New Deal), the G.I. Bill was highly problematic as it related to non-white Americans. ${ }^{138}$ Jim Crow laws were often reinforced and reproduced through this legislation due to local officials being granted the authority to disburse funds and many non-white Americans still found themselves unable to receive the low-interest housing loans or business start-up loans that their white peers enjoyed. ${ }^{139}$ A particular stain on the outcomes of this bill was that traditionally black colleges and universities

\footnotetext{
${ }^{135}$ Harold Perkins, "History of Universities," in International Handbook of Higher Education, ed. James J. F. Forest and Philip G. Altbach (New York, NY: Springer, 2007), 180.

${ }^{136}$ Rudolph, The American College and University: A History, 486.

${ }^{137}$ Fallis, Multiversities, Ideas, and Democracy, 60-61.

${ }^{138}$ Nick Kotz, "When Affirmative Action Was White: Uncivil Rights," New York Times, August 28, 2005, accessed on February 26, 2018, https://www.nytimes.com/2005/08/28/books/review/when-affirmativeaction-was-white-uncivil-rights.html?_r=0.

${ }^{139}$ Ibid.
} 
remained woefully underfunded and unable to enroll the tens of thousands of black veterans who sought to obtain the education promised them. The University of Pennsylvania, regarded as the "least discriminatory" of the Ivy League schools, only enrolled 46 black students out of a student body of 9,000 in $1946 .{ }^{140}$ While the G.I. Bill was generally favorable for veterans and higher education it can be forgotten that not all Americans received those positive benefits equally, and for all of the work education and policy sought to do for a democratic society they still served as agents of social reproduction. In this case, like so many others, that reproduction was to the benefit of the dominant group at the expense of the minoritized group. ${ }^{141}$

\section{Academic Freedom and Academic Tenure}

As universities saw dramatic changes in students and mission, they also saw a changing nature in the faculty who were still a central figure at any institution of higher education. The new emphasis on research was most keenly felt among the faculty, and this was a change that they largely welcomed. Enlightenment principles still held sway over much of academia, and there was no nobler pursuit than that of knowledge and truth. Professors were celebrated for the "disinterested" nature of their research; that is to say, if their research was couched in the notion that it was not politically biased, but a "pure" search for truth and knowledge. Such research occasionally brought faculty into conflict

\footnotetext{
${ }^{140}$ Ibid.

${ }^{141}$ Kotz reviews When Affirmative Action Was White: An Untold History of Racial Inequality in TwentiethCentury America by Ira Katznelson, which explores how the G.I. Bill and other legislation systematically disenfranchised and disadvantaged non-whites throughout the $20^{\text {th }}$ century. While the nuances of this discussion are outside of the scope of this thesis, it is nevertheless noteworthy, and anybody interested in those discussions would find this text illuminating.
} 
with university benefactors or similarly interested parties, but the value of such research not being governed by outside forces was felt so strongly that in 1915 the American Association of University Professors (AAUP) was established, and through a series of conferences ultimately created the 1940 Statement of Principles on Academic Freedom and Tenure (AAUP, 1940). ${ }^{142}$

Though this idea has in recent years come under attack, for much of the $20^{\text {th }}$ century academic tenure and academic freedom were staunchly guarded values. In short, they protected professors and gave them high levels of autonomy to teach as they wished and to pursue whatever research they desired within their field. Of course, such protections did not come easily, and if a new professor wished to obtain the rank of a tenured faculty member, they must first prove themselves as capable and valuable researchers by publishing in prominent journals with regularity, colloquially referred to as a "publish or perish" system. Eventually, faculty and faculty research came to become an integral part of the larger professionalization of higher education and universities in particular. ${ }^{143}$ The following section explores some more areas of this professionalization and sets the stage for discussion on the effects of that professionalization on universities as democratic institutions.

\footnotetext{
${ }^{142}$ American Association of University Professors, "1940 Statement of Principles on Academic Freedom and Tenure," accessed on September 6, 2016, https://www.aaup.org/file/1940\%20Statement.pdf.

${ }^{143}$ Rudolph, The American College and University: A History, 483-496.
} 


\section{Professionalism of Higher Education}

American colleges and universities saw an abrupt turn towards professionalism during the turn of the century in the demands and expectations of those who led them. Though perhaps colleges always preferred a "professional" college president, Veblen and his contemporaries proclaim that universities of his day required a "captain of erudition," a leader capable in finance, industry, and education. ${ }^{144}$ Frederick Rudolph quoted Rutherford B. Hayes who sat upon the Ohio State board after his term as the President of the United States who in 1890 gave voice to Veblen's proclamation in saying that in a college president,

We are looking for a man of fine appearance, of commanding presence, one who will impress the public; he must be a fine speaker at public assemblies; he must also be a scholar and a great teacher; he must be a preacher, also, as some think; he must be a man of winning manners; he must have tact so that he can get along with and govern the faculty; he must be popular with the student; he must also be a man of business training, a man of affairs; he must be a great administrator. ${ }^{145}$

Hayes astutely added after the fact that "there is no such man," but his words may have proven to not be so far off of the mark regarding expectations. As time wore on the college president as a public orator and savvy businessperson/fundraiser became less the ideal and more the expectation. ${ }^{146}$

\footnotetext{
${ }^{144}$ Veblen, The Higher Learning in America, 94.

${ }^{145}$ Rudolph, The American College and University: A History, 419.

${ }^{146}$ Peter D. Eckel and Adrianna Kezar, "The Intersection Authority of Boards, Presidents, Faculty: Toward Shared Leadership," in American Higher Education in the Twenty-First Century, $4^{\text {th }}$ ed., ed. Michael N.
} 
Furthermore, as universities became larger and more complex entities, what Kerr and Fallis aptly called 'multiversities,' the role of the president became ever more substantial and complex. ${ }^{147}$ Most modern universities see their president handling the day-to-day affairs of the university relatively little, those duties instead handled by a provost. ${ }^{148}$ Instead, college presidents spend a vast amount of their time operating in fundraising capacities, either soliciting donations from wealthy benefactors, larger appropriations from the state legislature, or as the CEO of the university's many business ventures designed to generate revenue with fewer strings attached to it. ${ }^{149}$ Some have argued that the powerhouse college president, such as Harvard's Charles Eliot, is a thing of the past, and while it seems unlikely one college president may affect higher education so widely again that does not mean that they no longer play a vital role. ${ }^{150}$ Hayes' notion of a college president appears to be more accurate now more than ever and so it comes as little surprise when universities in search of a president hire somebody who has already served as president elsewhere. So crucial is the position that many universities feel that to be their president one must already have experience in the position.

Bastedo, Philip G. Altbach, and Patricia J. Gumport (Baltimore, MD: Johns Hopkins University Press, 2016).

${ }^{147}$ Kerr, The Uses of the University; Fallis, Multiversity, Ideas, and Democracy, 3.

${ }^{148}$ Eckel and Kezar, "The Intersection Authority of Boards, Presidents, Faculty: Toward Shared Leadership."

${ }^{149}$ Ibid.

${ }^{150}$ Derek Bok, Higher Education in America, (Princeton, NJ: Princeton University Press, 2013), 47-50. 
Of course, it is not only the president of a university that has become a professionalized position. With the boom in student population resulting from the industrial revolution and legislation such as the G.I. Bill, universities found that it could no longer be left up to the faculty and the president to oversee the student body. Hosts of positions ranging from residence life directors, campus activity coordinators, diversity office officials, and several others have been created over the decades to compensate for the growing needs of a university. The bureaucracy of universities has become such that administrators outnumber all other groups at a university (save students themselves). Universities now are so awash in advisors, admissions officers, coordinators, marketers, and more that entire graduate degree programs, such as Higher Education Administration or College Student Personnel, have been created to train the legion of administrators necessary to fill all of these roles. The budgetary needs alone can be staggering, but of more significance may be the comprehensive, highly detailed policies required to coordinate and govern such a workforce. Their very presence implies a shift from what remained of Dewey's argument for growth-based education to a standards- and proficiency-based system.

However, it is worth noting that not all of these changes are problematic. Though massive university growth led to bloating in overhead and administration it also allowed for increasingly more people to have access to higher education, and, though it took longer to accomplish, that includes minoritized groups who less than a century ago would 
never have been admitted into colleges and universities. ${ }^{151}$ Though full equality is far from the norm, higher education has proven to be a vehicle for democratic progress in a way that arguably no other institution has been. Fallis went so far as to suggest that "The movement from elite to mass university education is surely one of the great success of the democratic project in the postwar era." ${ }^{\prime 152}$ While the history of universities in the U.S. is far from pristine, they have been amenable to positive and progressive change for the betterment of society. Universities have also proven to be sites for the masses to assert their authority and obtain their platform to engage in the work of democracy. The following section looks at how students came to join other interested parties in governing universities and how they used protests and other staples of American democratic tradition to have their voices heard and heeded.

\section{Student Activism and the 1960's}

Whether it was intended or not, among the most powerful displays of universities serving a democratic society has been the numerous examples of student activism that has taken place on school campuses or by students in their local communities. Readings illustrates how this is not unique to American democracy through his examination of France in 1968 when student riots and protests occurred at numerous locations over a variety of issues, but American colleges in the 1960's as a whole marked a significant

\footnotetext{
${ }^{151}$ Amy A. Bergerson, College Choice and Access to College: Moving Policy, Research, and Practice to the 21st Century (Hoboken, NJ: Wiley Periodicals Inc., 2009) 12.

${ }^{152}$ Fallis, Multiversities, Ideas, and Democracy, 61.
} 
turning point in student activism. ${ }^{153}$ So pronounced was this shift in how we viewed students and student power that Kuh remarked that this decade of student activism “overshadow[s] all earlier periods." 154 The 1960's saw among other countless examples 45 predominantly African-American students engaging in lunch counter sit-ins in Greensboro, NC, ${ }^{155}$ Mario Savio's passionate calls for reform of the University of California Berkeley, ${ }^{156}$ and the formation of, and articulation of desires, of the Black Panther Party by Huey P. Newton and Bobby Seale. ${ }^{157}$

The details and motivations of these and other examples of student activism have been thoroughly examined and contextualized in American history elsewhere, but what is of almost equal significance is the connection between universities and these examples of activism. In several cases (perhaps most) the institution itself did not actively support the students (and in some cases worked against them), but they were nevertheless sites where these students were able to come together, share ideas, organize, and mobilize. Whatever

${ }^{153}$ Readings, The University in Ruins, 135-149.

${ }^{154}$ George D. Kuh, "College Students Today: Why We Can't Leave Serendipity to Chance," in In Defense of Higher Education, ed. Philip G. Altbach, Patricia J. Gumport, and D. Bruce Johnstone (Baltimore, MD: The Johns Hopkins University Press, 2001), 284.

${ }^{155}$ New York Times, “45 Students Seized in Greensboro Sit-in,” April 22, 1960, accessed March 27, 2018, https://www.nytimes.com/1960/04/22/archives/45-students-seized-in-greensborositin.html?url=http\%3A\%2F\%2Ftimesmachine.nytimes.com\%2Ftimesmachine $\% 2 \mathrm{~F} 1960 \% 2 \mathrm{~F} 04 \% 2 \mathrm{~F} 22 \% 2$ F99856310.html\%3FpageNumber\%3D14.

\footnotetext{
${ }^{156}$ Michael Jackman, “Mario Savio's 'bodies upon the gears' speech - 50 years later,” Detroit Metro Times, December 1, 2014, accessed March 27, 2018, https://www.metrotimes.com/newshits/archives/2014/12/01/mario-savios-bodies-upon-the-gears-speech-50-years-later.

157 The Sixties Project, “October 1966 Black Panther Party Platform and Program,” University of Virginia at Charlottesville, accessed March 27, 2018, http://www2.iath.virginia.edu/sixties/HTML_docs/Resources/Primary/Manifestos/Panther_platform.html.
} 
was occurring with policy and the administration, there was still enough nature and culture at these institutions where the students (and some faculty and staff) were able to engage in democratic pursuits, including the questioning of authority and making effective calls for reform and change. Before the 1960's, there was a culture of shared governance in universities but as the $20^{\text {th }}$ century wore on that idea came to represent far more than just professors, the board of trustees, and the college president. ${ }^{158}$ Students joined in that shared governance and, for better or for worse, state legislators are taking an even keener interest in university activity as college degrees become more closely tied to personal and financial success in the public discourse. This change is evidenced by the fact that 37 states have instituted some form of performance-based funding models in higher education. $^{159}$

\section{Summary}

This chapter helps us understand how universities have related to American democracy in the past, and it provides a preview of how universities came to be driven by market-logic. Veblen and Hutchins, in particular, were very concerned a century ago with the preoccupation of universities with money and generating revenue. Their concern was not limited to funding from private entities but included state funding, which they argued also came with many conditions that may inhibit the work of universities. The decades

${ }^{158}$ Bok, Higher Education in America, 44-71.

159 "Performance-Based Funding for Higher Education," National Conference of State Legislatures, accessed April 29, 2018, http://www.ncsl.org/research/education/performance-funding.aspx. 
since have proven at least some of those concerns (if not all) valid and helps us answer what issues are causing this current crisis of democracy that the U.S. is facing.

In the chapter that follows I will explore more thoroughly the state of modern-day universities as democratic institutions and closely examine some of the forces that are undermining and subverting that democratic nature. Chief among these concerns is the effect of neoliberalism on university policy and governance but, as the literature has shown, many of these effects are not new. Instead, I will argue that there has been an intensification of these effects in recent decades and that this intensification is poised to significantly undermine much of the progress universities have made throughout American history as institutions of democracy. Throughout this discourse, it is important to remember that I am not attempting to romanticize the past, nor am I calling for a return to any "golden age" that probably never existed. As Readings so eloquently argues, whatever the university was before, be it a university of culture or something else entirely, that university is now in "ruins," and it is the responsibility of university officials now to determine how best to "dwell within the ruins" of this new university. ${ }^{160}$ I hope to explore this new ruined university, and in that exploration, offer some hope that not only is there something left to salvage, but that universities may be better positioned now to serve democracy than they ever did previously.

\footnotetext{
${ }^{160}$ Readings, The University in Ruins, 166-179.
} 


\section{CHAPTER IV}

\section{THE CORPORATE UNIVERSITY AND DEMOCRACY}

Bill Readings offers a thorough and well-reasoned analysis of the concept of "excellence" in higher education. ${ }^{161}$ Excellence, as Readings puts it, is meaningful for its lack of meaning. It appears everywhere in the new corporate university because "the general applicability of the notion is in direct relation to its emptiness." ${ }^{162}$ When Readings published his book that explored this idea and its impact on universities "excellence" was already making its way into higher education discourse by appearing in program and department names as well as university mission statements. By infusing "excellence" into every facet of the university officials could then claim they exhibited "excellence" and were thus worthy of the recognition, prestige, and funding such a designation implied. However, later in this chapter, I will argue that years later what Readings observed in the 1990's has evolved into its next form. However, before that discussion can occur it is important to analyze the neoliberal concepts and ideologies that gave rise to this notion of "excellence" and the corporate university as it exists today. The first section of this chapter explores this idea while the remainder of the chapter explores some of its manifestations in higher education.

\section{Neoliberalism and Higher Education}

Neoliberal thought is made up of movements and initiatives that work to privatize public institutions and to allow a free and unregulated market to dictate the course of

\footnotetext{
${ }^{161}$ Ibid., 21-43.

${ }^{162}$ Ibid., 23.
} 
events. As Stephen Gill illustrates, this is done under the belief that it is the free market that can best determine the needs of society and that once the market achieves maximum freedom then so will humanity. ${ }^{163}$ However, Gill goes on to conclude this comes with some alarming consequences. Gill suggests that "The logic of unfettered market forces, after all, is to increase global inequality." ${ }^{164}$ Other scholars refer to this as "academic capitalism," but it amounts to the same phenomenon - the infusion of market forces and market thinking in education. ${ }^{165}$

Two such scholars, Sheila Slaughter and Gary Rhoades, point to the 1972 amendment of The Higher Education of 1965, which created the Basic Education Opportunity Grants (now known as Pell Grants) as the genesis of the marketization of student financial aid by giving the federal dollars directly to students instead of the institutions. In this way, a marketplace was created allowing students to take their federal monies (grants and student loans) to "proprietary" institutions, many of which were predatory and ushered in a wave of individuals going into default on their student debt, leading to an overall decrease in federal funding. ${ }^{166}$ Slaughter has highlighted in various works the nature of academic capitalism and its effect on higher education policy. As one

\footnotetext{
${ }^{163}$ Stephen Gill, "Knowledge, Politics, and Neo-Liberal Political Economy," in Political Economy and the Changing Global Order, eds. Richard Stubbs and Geoffrey R. D. Underhill (New York, NY: St. Martin's Press, 1994), 81.

${ }^{164}$ Ibid., 85 .

${ }^{165}$ Sheila Slaughter and Gary Rhoades, "The Policy Climate for Academic Capitalism," in Academic Capitalism and the New Economy: Markets, State, and Higher Education (Baltimore, MD: Johns Hopkins University Press, 2004), 35.

${ }^{166}$ Ibid.
} 
example, multiple groups of business leaders helped policymakers and leaders in higher education craft policies, and ultimately laws, that allow private corporations to profit off of federally funded research and to allow even more partnerships between public universities and private corporations. ${ }^{167}$

Another, perhaps more insidious, result of neoliberalism is how it has affected how universities, and the students who attend them, view education. Levidow discusses how, "In North America, many universities have adopted entrepreneurial practices. They act not only as business partners, but also as businesses in themselves. They develop profit-making activities through university resources, faculty and student labour."168 Levidow goes on to illustrate how policy changes at universities redefine students as consumers and thus subject to market research. Saunders explores this student-consumer orientation in detail and highlights the internal contradictions therein. ${ }^{169}$ However, as Saunders goes on to state, this is not an appropriate orientation under which we should consider students. Notably, to exist in the free market of education students (now customers) would have to have a full understanding of the value of the education (now product or commodity) that they are "purchasing." ${ }^{170}$ However, such expectations are

\footnotetext{
${ }^{167}$ Sheila Slaughter, "National Higher Education Policies in a Global Economy," in Universities and Globalization: Critical Perspectives, eds. Jan Currie and Janice Newson (Thousand Oaks: SAGE, 1998), 63.

${ }^{168}$ Les Levidow, "Neoliberal Agendas for Higher Education," in Neoliberalism: A Critical Reader, eds. Alfredo Saad-Filho and Deborah Johnston (London: Pluto Press, 2005), 157.

${ }^{169}$ Saunders, "Exploring a Customer Orientation," 197-219.

${ }^{170}$ Ibid., 206.
} 
often unrealistic and the decisions that drive students to choose one school over another, or one major of study over another, are more social or accidental than anything else. ${ }^{171}$

In summary, neoliberal practices have provided an avenue for private entities to bend public institutions, such as universities, to adopt more free-market policies that in turn de-emphasize the role of the public in higher education. Instead, universities come to primarily serve those private benefactors and only serve the public secondarily. The intensification of this academic capitalism leads to policies that negatively impact both faculty and students, but it also negatively impacts the way in which society views education and universities in particular. By viewing students as consumers and universities as businesses that offer a product or a service, society appears to be coming to accept these negative impacts as "a part of doing business." The remainder of this chapter explores some of these consequences and begins to explore how this trend may be navigated because it is increasingly clear that it is not something that could be reversed.

\section{Excellence Through Performance-Based Funding}

As stated previously, 37 states now maintain a performance-based funding model for higher education. These models seek to create standards for public universities to follow to receive additional funds above their base funding level. These funding models vary by state, but all follow the pattern of creating metrics by which to evaluate public colleges and universities in the state and award additional funding to those institutions that perform well on those metrics. Such policies reflect a general trend of accountability in

\footnotetext{
${ }^{171}$ Ibid., 206-207.
} 
higher education (which Readings tells us are mere "accounting" practices). ${ }^{172}$ In describing the thinking behind the model, the Florida Board of Governors describes the model as having, "four guiding principles: 1) use metrics that align with SUS Strategic Plan goals, 2) reward Excellence or Improvement, 3) have a few clear, simple metrics, and 4) acknowledge the unique mission of the different institutions." ${ }^{\text {173 }}$ It is plain to see how "excellence" has left its mark on the Florida model, but what has perhaps evolved since Readings' time is the attempt to define and specify what "excellence" actually means.

In the state of Florida, excellence in higher education is reduced to 10 quantitatively measured metrics that are included in each university annual report. ${ }^{174}$ These metrics represent what is to be the standard for which all public colleges and universities are to strive to achieve. In other words, to be "excellent" is to perform well in these metrics. By itself, this model would have no true meaning or power. However, given the financial pressures that virtually all public institutions face, the potential for millions of dollars in extra state funds is so powerful that universities are beginning to alter admissions practices, academic support services, and in rare cases degree requirements to put forth "more excellent" numbers on their audit report. ${ }^{175}$ That is not to

\footnotetext{
${ }^{172}$ Jeroen Huisman and Jan Currie, “Accountability in Higher Education: Bridge over Troubled Water?" Higher Education 48, no. 4 (December 2004), 529.

173 "Board of Governors Performance Funding Model Overview," Florida Board of Governors, accessed May 1, 2018, http://www.flbog.edu/board/office/budget/_doc/performance_funding/Overview-DocPerformance-Funding-10-Metric-Model-Condensed-Version.pdf.

${ }^{174}$ Ibid.

${ }^{175}$ Florida International University, for example, has created as many as 11 different admissions pathways. Admitted students are placed on a given pathway based on their incoming academic profile and,
} 
suggest that these new funding models are not without merit. If universities are to be evaluated for funding purposes holding them accountable for student success may be preferable to funding universities based on enrollment size, which incentives universities to enroll as many students as they can with no heed paid to whether or not that student will succeed. However, Readings posited that such accountability regimes would create "accountants" out of university officials, only concerned with the moving around of numbers, which appears to have become the case. ${ }^{176}$

So why is it that universities are being pushed toward these accountability measures in the first place? The brief answer is that government officials are increasingly pressured by their constituents to ensure that if a student is going to take on the debt necessary to obtain a college degree, then there ought to be some assurance on the back end that the debt incurred will have been worth it. This need for assurance presents two possible options for legislators: they can dedicate the massive amount of money required to offer free higher education at public universities, or they can create a system of accountability measures that ensure that the "market value" of the degrees offered is enough to offset student debt. Predictably, most legislators (with perhaps some exceptions such as the state of New York) have opted for the latter. For universities to maintain funding and receive comparable increases in funding relative to their peers they must meet these accountability standards. For decades universities were forced to attract

\footnotetext{
interestingly, some of these pathways are not counted in certain Florida metrics. For example, students admitted into the Early Fall Supported Transition to Excellence Program (STEP) do not count in the second-year retention metrics as they are not full-time students during the first fall semester.

${ }^{176}$ Reading, The University in Ruins, 21-43.
} 
students to their schools and, in so doing, began to act like corporations offering a "product" to their potential "customers," but in recent years Readings' suggestion that "the university is not just like a corporation; it is a corporation" appears truer than ever. ${ }^{177}$

\section{Measuring the Corporate University}

While some may recoil at the idea of the corporate university and what it represents nuance must be applied. Researchers might think there is a good reason to believe that the concerns raised about higher education and democratic values are not well founded. Following on the work of Ernest Pascarella and Patrick Terenzini, ${ }^{178}$ Mayhew et al. examine the moral development that occurs in colleges and concludes that "college degrees serve as conduits for economic mobility and often, more important, as platforms for social change." ${ }^{179}$ However, these authors admit that their understanding of moral development comes from a Kohlbergian point of view and that perspective is not widely enough accepted as to be empirically true. Furthermore, in their review of studies during the last 15 or so years the authors confess that in most studies, "Rather than question if college-going has an influence on moral development, scholars assumed this

\footnotetext{
${ }^{177}$ Ibid., 22.

${ }^{178}$ Ernest T. Pascarella and Patrick T. Terenzini, How College Affects Students (San Francisco, CA: JosseyBass, 1991).; Ernest T. Pascarella and Patrick T. Terenzini, How College Affects Students: A Third Decade of Research, $2^{\text {nd }}$ ed. (San Francisco, CA: Jossey-Bass, 2005).

${ }^{179}$ Mayhew et al., How College Affects Students: $21^{\text {st }}$ Century Evidence That Higher Education Works, $3^{\text {rd }}$ ed. (San Francisco, CA: Jossey-Bass, 2016), 360.
} 
relationship existed and focused instead on investigating the specific practices and psychological mechanisms that influence this change."

So what is it that we may conclude then? In defining the needs of American democracy, Fallis outlined four significant areas: addressing unemployment, social insurance, developing social citizenship, and a progressive taxation system that funds the welfare state. ${ }^{181}$ So do universities address these needs? The evidence does appear to be conclusive on the effects of higher education on employment, but it is less clear if higher education is affecting government policy on social insurance or taxation policy, and it appears to be even more nebulous to guess at the development of social citizenship.

Following recent trends in government policy, one may argue that higher education is not doing enough to promote progressive taxation or social insurance policies, but such an analysis is outside of the scope of this study. Of more relevance may be examining the development of social citizenship that occurs on campus. Existing empirical analyses may draw statistically significant conclusions based on particular ideas that relate to concepts of citizenship. However, when one considers how narrow these educational experiences are defined to be (let alone considerations of effect size, which were often small) it becomes difficult to say with any certainty how colleges are doing when it comes to developing social citizenship. Like the researchers in the studies reviewed by Mayhew et al., universities are making assumptions that they are developing these qualities of their students, but in reality, nobody is sure either way.

\footnotetext{
${ }^{180}$ Ibid., 339.

${ }^{181}$ Fallis, Multiversities, Ideas, and Democracy, 88.
} 
This might seem like a cause for concern and, following the logic of the university's accountability systems, worthy of creating high-stakes funding models to empirically determine if Florida International University (FIU) is "excellent" in developing social citizenship in the same manner that FIU is tracked and measured in producing graduates who are employed and earn a certain income within one year after college. Such metrics are notable by their absence, but then how might such a system be defined? Current systems of measurement rely too narrowly on quantitative annual reports created by university officials. Such means cannot adequately measure a graduate's ability to be a citizen in our society, which would include properly engaging with our institutions of democracy. ${ }^{182}$

The absence of such metrics may not itself be an indictment of universities or suggest that it is not of concern. FIU may not be tracked for its citizenship education practices by the Board of Governors, but they do have policies that imply citizenship education is valued. Global Learning is a well-resourced and embedded department at FIU that has received some recognition for its programs, which include a Global Learning academic requirement fulfilled by taking two courses designated as Global Learning courses, educational experiences such as extracurricular roundtable discussions with experts in a variety of fields, and other programs and practices that promote global

\footnotetext{
${ }^{182}$ Every metric in the Florida Board of Governors Performance-Based Funding Model and their related models such as "Pre-Eminent Research University" are quantitative metrics supplied to the Board of Governors on each public university's annual report.
} 
citizenship. ${ }^{183}$ These programs may well promote the social citizenship that Fallis claimed American democracy required, and it may even be that they accomplish the task very well. However, given the logic of current governing forces, it could be argued that if the Board of Governors valued these ideas, then why do they not measure them and provide funding to universities based on outcomes in these areas in the same way?

Among the silver linings to Florida's accountability standards for universities is that it has forced its universities to be more concerned with student success in college. It is no longer enough to provide access to a college education, but universities must also ensure that students can succeed once they go to college and are positioned to obtain a job after they graduate. So where is the assurance that universities are providing similar outcomes for concepts such as social citizenship? Individual universities may be concerned about it, just as individual universities may have already been concerned with student success, but there does not appear to be a broader effort to ensure it is occurring. That is the danger of such accountability systems in education and the result of years of intense corporatization of higher education. Some things are forgotten or just left out. So, what is it that is driving the missions of universities?

Readings said that excellence was an ultimately meaningless term with no external referent. Its use signified an emptiness to the central mission of universities, but in that emptiness, we may at least be able to "dwell within the ruins" of the university.

\footnotetext{
183 "FIU recognized for innovative global learning initiatives," Florida International University, accessed May 1, 2018, https://goglobal.fiu.edu/2016/01/25/4554.
} 
Readings suggested creating "communities of dissensus." ${ }^{184}$ Gary Rolfe took this concept further in suggesting university faculty exist in a "paraversity," a parallel university that is ephemeral and apart from the bureaucratic corporate university. ${ }^{185}$ In this paraversity faculty would continuously shift in their thinking and practices, always one step ahead of the accountability regime by inhabiting the spaces that metrics did not.

While this perspective has merit, it mistakenly positions faculty as the center of the university. Faculty may have once been at the center, but the corporate university has come to be dominated by administrators, and it is administrators who will determine its activities, including what is required of faculty. Administrators may not say much about what goes on in a classroom, but their agendas are maintained by ensuring whether or not that classroom exists for the professor to teach in. In this way, the faculty becomes unwitting middle-managers enforcing policies that are of concern to university officials. It may not matter what particular text a faculty chooses for their course or the nature of the assignments given to students. What matters is that faculty can articulate how that text or those assignments meet specific learning outcomes in line with program goals, department goals, and university goals, which increasingly are tied to these high-stakes accountability models. If universities, and the accountability regimes which they exist under, are ambivalent to the specific needs of democracy and not actively prioritizing

\footnotetext{
${ }^{184}$ Readings, The University in Ruins, 180-193.

${ }^{185}$ Gary Rolfe, The University in Dissent: Scholarship in the Corporate University (New York, NY: Routledge, 2013), 35.
} 
those outcomes even within their logic of accountability, then what is to be done? This final section hopes to offer a way forward in navigating those tensions.

\section{Corporate Universities and the Public}

It is tempting to suggest that universities and their governing officials dispel the use of standards and accountability, and such a notion may even have some support. ${ }^{186}$ However, such critiques ignore both the few positive aspects such standards have and, more problematically, ignore the reality of the situation. Reversing course to "the way things were" may appeal to some but for those who were either excluded from or taken advantage of by the university of yesteryear the current situation, bleak as it may sometimes seem, is still preferable. There is also little evidence to suggest that universities historically did more, or even as much, as modern universities to promote democratic citizenship. Fallis noted that having a job is the most clearly defined and crucial element to be a part of American democracy, and so universities fixation on that outcome is not without merit. What, then, are university officials concerned with such things to do if reversing course is not an option?

I put forth that the most vital work missing from universities today is reinvigorating the idea of the public. Neoliberalism has worked over many years now to dismantle the idea of the public and that dismantling has manifested itself in students being seen as, and seeing themselves as, private consumers of their education. Furthermore, this orientation is not solely applied to students at a university. Faculty are

\footnotetext{
186 Jerry Z. Muller, "The Tyranny of Metrics," The Chronicle of Higher Education, January 21, 2018, accessed January 22, 2018, https://www.chronicle.com/article/The-Tyranny-of-Metrics/242269.
} 
losing protections such as academic tenure that allow them to act as public intellectuals, and other university officials including senior administrators and academic support staff (an ever-growing population at most universities) never had such protections in the first place. ${ }^{187}$ Universities cannot seek to address democratic education and socialization by merely creating one or two mandatory courses on civic literacy (as the state of Florida has now done). ${ }^{188}$ While such courses may have some value, a single three-credit course taken by freshmen and sophomores hardly constitutes democratic socialization.

Instead, university officials must work to create, support, and reinforce the public in a way that is substantive and impactful. However, earlier this study discussed how there is no one public, that publics arise in response to a problem imposed on them by a governing entity, and that once the issue is resolved the public will disappear. So how do universities support this? Some may argue they already do as virtually every institution allows for student interest groups to form and student government is now an established tradition including giving students a seat on a university's governing board.

However, this kind of support falls short when students come together to address concerns with the university itself. In fact, when students do form together to protest and call for change at their institution, they are often attacked and criticized by detractors who say they are "coddled" and "have too much free time." ${ }^{189}$ Such scorn implies that students

\footnotetext{
${ }^{187}$ Colleen Flaherty, “Killing Tenure,” Inside Higher Ed, January 13, 2017, accessed May 1, 2018, https://www.insidehighered.com/news/2017/01/13/legislation-two-states-seeks-eliminate-tenure-publichigher-education.

188 "Postsecondary Civics Literacy," Florida Department of Education, accessed May 1, 2018, http://www.fldoe.org/policy/articulation/postsec-civics-lit.stml.

${ }^{189}$ Tom Lindsay, "One More Reason For Campus Protests: Students With Little Homework, Lots Of Time On Their Hands," Forbes, March 31, 2016, accessed May 1, 2018,
} 
are not to be concerned with university governance and have little to no role in overseeing it. What may be most concerning of all, is that students may not see themselves as responsible for the governance of their university. It would be easy to see why students feel this way as many university officials, faculty, administration, and support staff alike, do not seem to see students as a central part of university governance. In an article for The Chronicle of Higher Education, Gary Olson discussed shared governance and the tensions between faculty and administrators over what precisely that means. However, in this entire discussion "student" was only uttered three times, and each time it was made clear that students had a limited role at best in university governance. $^{190}$

These often token avenues of student governance on only minor issues highlight how universities are not being run democratically. However, even if university officials agreed to hand over governance wholesale to students, there is still the all too real issue of student apathy when it comes to university governance. For example, students at MIT once elected a bag of popcorn as its student government representative. ${ }^{191}$ This kind of apathy is reflective of a more significant issue in the U.S. particularly when it comes to

https://www.forbes.com/sites/tomlindsay/2016/03/31/one-more-reason-for-campus-protests-students-withlittle-homework-lots-of-time-on-their-hands/\#79f7f2625e6b

${ }^{190}$ Gary A Olson, “Exactly What is 'Shared Governance’?” Chronicle of Higher Education, July 23, 2009, accessed May 1, 2018, https:/www.chronicle.com/article/Exactly-What-Is-Shared/47065.

${ }^{191}$ Menachem Wecker, “College Student Leaders Divided on Benefits of Student Government," U.S. News and World Report, April 5, 2012, accessed May 1, 2018, https://www.usnews.com/education/bestcolleges/articles/2012/04/05/college-student-leaders-divided-on-benefits-of-student-government. 
elections -where the U.S. ranks $31^{\text {st }}$ out of 35 countries for voter turnout. ${ }^{192}$ Some of those numbers may be attributed to voter disenfranchisement, but by and large, there is a real issue of general apathy.

Perhaps this question of apathy in governance gets to the crux of the matter at hand and the core of what universities ought to do moving forward. The systems may exist for students to engage in university governance, indeed for the American populace to engage in American governance, but as Dewey claimed, for a public to influence the governing body it must first realize itself as a public. That self-realization is perhaps less straightforward than was previously imagined, and with the increased privatization of our public institutions what value is there to be seen by individuals in forming as a public in the first place?

There is room for hope though. Since the economic recession public trust in labor unions has steadily increased, indicating that when faced with an issue, people are still willing and able to form together as a public. ${ }^{193}$ Furthermore, recent waves of activism such as the \#MeToo movement protesting sexual violence, the March For Our Lives rallies advocating for gun control, and countless protests on and off of university campuses protesting racial bias and discrimination indicates that the energy is there for political engagement. Despite this, efforts to privatize public institutions undermine these efforts of engagement and coming together as a public, just as those efforts have so

\footnotetext{
${ }^{192}$ Michael D. Regan, "Why is voter turnout so low in the U.S.?" PBS Politics, November 6, 2016, accessed May 1, 2018, https://www.pbs.org/newshour/politics/voter-turnout-united-states.

193 “Labor Unions," Gallup, accessed May 1, 2018, http://news.gallup.com/poll/12751/labor-unions.aspx.
} 
negatively influenced our political systems. ${ }^{194}$ Perhaps this is why Wendy Brown concluded that "democracy could not be counted on to save the higher education on which it depends." 195

If democracy depends on higher education but can do little to save it, then higher education must alter itself from within to reinvigorate democracy and thus empower it to in turn save colleges and universities. This symbiotic relationship starts with universities fully embodying democratic institutions in all of their practices. It is not enough to be a democratic institution when students are around, in the classroom or an academic advisor's office. Universities must examine their entire infrastructure and determine if they are genuinely democratic. For example, are adjunct faculty considered equal with full professors? Does a coordinator of a campus life program have significant representation in university governance? Most importantly, are students challenged to take a role in university governance and held to any standard to do so?

\section{Summary}

This chapter sought to highlight the current issues facing American universities and democracy today and how those issues are the result of a rise in neoliberal ideology and practice. Earlier in this chapter, I suggested that it would be tempting to get rid of such practices including accountability structures in higher education, but if they are indeed here to stay (and it is hard to argue they are not), then should universities not include all aspects germane to democratic socialization in their accountability measures?

\footnotetext{
${ }^{194}$ Lafer, "The Corporate Assault on Higher Education."

${ }^{195}$ Brown, Undoing the Demos: Neoliberalism's Stealth Revolution, 210.
} 
If done well, this could force universities and their governing bodies to consider alternative modes of assessment outside of narrow quantitative measures and instead embrace a broader view of the goals and necessary outcomes of higher education. Of course, it is possible (perhaps even likely) that governing boards merely attempt to quantify democratic socialization with empirical methods, and the result would be a tangled mess of half-baked metrics. Nevertheless, universities and those of us who make our careers in them must ask ourselves what is worse, trying and failing to incorporate democratic ideals into our accountability measures making them more of a priority or ignoring them altogether and hoping that the situation resolves itself. 


\section{CHAPTER V}

\section{FINAL CONCLUSIONS AND IMPLICATIONS}

This study set out to address the question of the role universities play in American democracy. Other derivative questions included the issues currently facing democracy, the role universities play in remedying the current crisis faced by democracy, and the role universities should play in democracy. These questions are deeply nuanced, and I can only hope that I have offered somewhat satisfactory conclusions to them. However, I do not view this study as the final word on any of the subjects, and so I acknowledge that the answers to some may be unsatisfactory in that they only beg more questions and further thought on the matter. Nevertheless, in this final chapter, I will first go through each of the initial questions and offer a brief overview of this study's findings. For the sake of organization, I will first address the three derivative questions and then conclude this first section by addressing the primary question that drove the entire study. Following that will be a section offering considerations for future work and directions I would like to see this conversation go.

\section{What are the Issues Currently Facing Democracy?}

Democracy in the U.S. can be thought of as having always been in crisis. As discussed previously, theoretical democracy may be the ideal to society strives, but practicalities make it all but impossible to achieve. Any version of democracy that exists can only be a problematic adaptation that makes compromises of the ideal in the name of achieving progress on the business of the day. In the U.S., we employ a representative democracy and have created a democratic system whereby the population must have a certain amount of trust that their elected officials operate on their behalf. It is only when 
that trust is revealed to have been violated that citizens must come together and respond accordingly, often by voting out the offending public official.

However, while these crises have always plagued American democracy, a particular issue has come to the fore in recent years in the increased privatization of public institutions through the logic of neoliberalism. Lobbyists and the wealthiest among us use their considerable influence to privatize what are, or at least should be, public institutions such as education. This deterioration of the public through the dismantling of its institutions has bred a lack of visibility and an overall lack of trust in democracy. Efforts to privatize American institutions capitalized on the opportunity of the recession and the resultant lack of public funds, which forced so many institutions, but particularly universities, to seek funds elsewhere, which primarily came in the form of donations from private benefactors and private companies.

It is the very privacy of that funding source and that relationship that makes it so difficult for any potential public to form together in response to an issue because the privacy conceals from the public who or what exactly is harming them in the first place. With no public object or offending party for the public to organize and send its officials against the public has little recourse to respond at all. It is here where democracy faces its current crisis, the public has no purpose and thus a fleeting existence with no sense of the source of their problems.

\section{What Role do Universities Play in Remedying the Current Crisis Faced by Democracy?}

As discussed in the previous section, universities must become active supporters and advocates for the public by making transparent all of their actions, partnerships, and 
policies. As institutions of democracy, universities must embody democratic ideals which include allowing the public full access to its proceedings so that when a group feels that it has been aggrieved by a university and forms together as a public, they have some recourse to make their issues heard allowing for the possibility for it to be addressed. Such oversight is crucial not just to the business of a public institution, but to the public placing its trust in that institution. Without trust in public institutions, there is no trust in democracy as a whole.

Furthermore, I discussed early in this thesis how Alexis de Tocqueville cautioned against the "tyranny of the majority" in his work and how several others have taken that further to include the tyranny of a compliant majority, that is to say, a majority which unwittingly acts against itself in the interests of a small but powerful minority. The increased privatization has allowed for powerful elites to overly dominate and influence American governance in all of its institutions including the state and its schools. As public intellectuals, university officials are tasked with being watchdogs on this kind of behavior, and they are to speak out in a way that can be readily understood by the rest of the populace. It does no good for university researchers to reside in an ivory tower and care not if the rest of the population hears or understands what they have to say, and it is this latter point in which there is much work to do. Scholars may research and publish their findings to no end, but if it does not have any effect, implicitly or explicitly, on society, then it has no purpose at all.

\section{What Role Should Universities Play in Democratic Governance?}

In considering what role universities should play in democratic governance, it is useful to recall Fallis' articulation of the needs of democracy. Those four aspects are 
addressing unemployment, social insurance, social citizenship, and creating progressive taxation which funds the welfare state. It should brook no argument that it is in this first ideal of addressing unemployment that universities excel the most and are already being pressured to improve by state legislatures. As odious as universities may find the funding models that push these agendas they are not entirely without merit. Having a well-paying job is the most crucial factor in one's ability to participate as a democratic citizen, and a college degree is the most reliable way to obtain that job. While it offers no guarantees, it undoubtedly positions college graduates better than any other public institution may.

Social insurance and progressive taxation are both similar issues to be addressed as relates to universities. Scholarly research can be used to advocate for and support these demands of government officials, but perhaps more important is what this asks of universities as democratic institutions. It is no longer acceptable to feign the disinterested scholar pursuing research and knowledge for its own sake. This notion promotes a false idea that any such research can exist without bias. Instead of seeking to cover up or ignore any inherent biases it is more important for researchers and universities to make their obligations and commitments more visible and to allow the public to determine how to receive those commitments. In supporting democracy, universities must promote a social good that allows ever more people to participate in democracy and that means discussing and advocating for those outcomes. In offering a perspective as objective fact scholars risk the trust of the very people they hope to serve and, as stated previously, that trust is central to democracy and its institutions. 


\section{What Role do Universities Play in American Democracy?}

In conclusion, I am now faced with the central question at hand, and I offer here what I have said in various ways throughout this study and these conclusions. Universities are institutions of democracy, and so first and foremost they must embody it. The reason for this is because it is without question that universities provide the crucial education for the overwhelming majority of American leaders, including government officials, most prominent CEO's, but also the majority of its skilled workforce, community leaders, and perhaps most importantly American teachers. A vast majority of these highly influential positions require a college education, and while it can be debated whether or not that education is necessary for the task at hand, what is beyond dispute is the value placed upon the college degree in American society.

Universities have no one role in American democracy but many. They must prepare people for technical and skilled labor. They must provide the research that supports not only those industries but the public-sector work that seeks equitable solutions to societal deficiencies based on race, class, gender, sexuality, and other factors used to exclude or suppress individuals or groups of individuals. But universities must also act as one medium (while actively supporting others) through which scholars can pass along relevant information to the public and its elected officials - information that will work to the benefit of these previous endeavors. Universities are obligated to not only allow but to support and promote its members to be the driving force of American intellectualism as relates to American democracy. This obligation means that universities must have a proactive role in offering a discourse on all aspects of American democracy. While by no means the arbiters of what is right and wrong in democratic discourse, 
universities must offer their voice to that discourse through their conducted research and the discourses of its faculty, students, and academic staff.

In fairness, this is a challenging proposition for universities to take on. They must provide the public space for all parties to offer discourse on American institutions, but they must also offer their own perspective to that discourse. This relationship could only be navigated if universities thoroughly practice the responsibility to be public and transparent. Biases and personal interests are not to be hidden and concealed, but instead actively revealed and made public. Failure to do so undermines the intellectual value universities offer society because it can shape ways of thinking that at first appear to benefit the public at large, but in reality, only benefit an elite few. In short, by not making commitments and biases public universities only contribute to the creation of the compliant majority.

There are some examples of how some educators have worked to accomplish this in K-12 schooling. In a high school social studies class students engaged with the national debate that was going on at the time over the Confederate flag, and whether or not it should be flown over public buildings. ${ }^{196}$ By employing a critical pedagogy, the educators worked to have their students think critically and deeply about this topic in such a way where the goal was not to convince the other side of your viewpoint but to instead understand the thinking and motivations behind why they thought the way that they did.

\footnotetext{
${ }^{196}$ Susan L. Schramm-Pate and Richard Lussier, "Teaching Students How to Think Critically: The Confederate Flag Controversy in the High School Social Studies Classroom," High School Journal 87, no. 2 (December 2003-January 2004), 56-65.
} 
Another possibility is through the use of empowering education, which Ira Shor describes as, "a critical-democratic pedagogy for self and social change. It is a studentcentered program for multicultural democracy in school and society." ${ }^{197}$ Such practices promote the notion that classrooms should be spaces where the learning process is negotiated between student and teacher. The teacher may act as the leader, but there is "mutual student-teacher authority" where students gains are not only self-centered but consider the public welfare as well. ${ }^{198}$ Such structures not only provide essential socialization for the students, but I would argue they would create a democratic atmosphere throughout the entirety of the school where decisions are negotiated democratically instead of passed top-down, but only if they are practiced throughout an institution. The education, in this way at least, is as much for the educator as it is the educated.

\section{Implications}

As stated before, this study set out to offer a discourse on the intersection of fields so broad and varied that the number of perspectives that were not adequately engaged with or in an appropriate depth is staggering to consider. However, I do believe this study has revealed a few considerations that are worthy of future study. I will do my best to outline them briefly here.

\footnotetext{
${ }^{197}$ Ira Shor, "Education is Politics: An Agenda for Empowerment," in Empowering Education: Critical Teaching for Social Change (Chicago, IL: University of Chicago Press, 1992), 15.

${ }^{198}$ Ibid., 16.
} 
First, in analyzing the needs of democracy, it became apparent that while many universities attempt to do work in the area of socializing students to society, there is much work that still needs to be done. Current efforts such as Florida creating a civics literacy requirement in the curriculum may be laudable in their attempt, but I fear may fall woefully short of their desired goals. However, so many solutions in higher education seem to find their solutions in curricular changes. While I support these efforts, significant consideration ought to be given to the environment in which students are taking these classes. Are universities truly democratic institutions? Do their senior faculty and senior administrators obtain those positions in genuinely democratic ways, or through autocratic systems that only exist to reinforce the status quo? Ought universities to be concerned about the socialization of more than just students? What of the professoriate? The academic support staff? The provost? If being a democratic citizen is important is it not also important to consider these individuals as well? It would be folly to assume students finish their degree and are "done" learning or being socialized, so perhaps more consideration should be given to the rest of the university as well.

This understanding of institutions embodying democracy can be understood in Dewey's own words on the subject when he stated "A democracy is more than a form of government; it is primarily a mode of associated living, of conjoint communicated experience." ${ }^{199}$ Dewey goes on to suggest that the actions one takes must refer to others of the group, and that one must consider the actions of others to guide their own. Only in

\footnotetext{
${ }^{199}$ Dewey, Democracy and Education, 87.
} 
this way could barriers such as race and gender be overcome. Universities must adopt a democratic mode of living if they are to truly function as democratic institutions.

Second, much has been said about members of the university as public intellectuals and the need to properly communicate their work in a consumable form to those outside of the academic community. However, there still appears to be a disconnect between what researchers say is valid or important, and what the rest of society, particularly governing officials, seem to value. This is not to suggest that scholars are right and the rest of society is wrong. Instead, it does not seem to be the case that those of the academic community are in the same discourses as those who are not. It is the responsibility of scholars and academics to merge scholarly discourse and the wider discourse on issues where it is appropriate and necessary. While the typical person may not be concerned with research methodologies as such, they may be very concerned about the results and conclusions of that research, but it is on the scholar and the institutions to bridge that gap. Lippmann and Dewey agreed on this point that American democracy requires experts and representatives to both critique society's rules and to engage in the public discourse about how to remedy issues as they arise.

Finally, there is considerable need for research not in exploring and articulating the effects of neoliberalism, but in actually combating its effects. However, universities and education as a whole is not the only institutions that suffer from these effects. Dewey observed that addressing all of society's woes is essentially an intellectual problem, one where seemingly disparate issues or concerns (and thus separate publics) are actually suffering from the same root cause. Addressing this will require significant intellectual work, a task academics are uniquely suited for. 
One may say that universities should not act like corporations, nor treat students as customers, but this amounts to naught if meaningful solutions are not provided that disrupt this orientation. Such disruptions require addressing issues and systems both close to and far outside of the university, but that is indeed the work of higher education. To look at all aspects of society and work to improve them. To ask the difficult questions and then work to provide difficult answers. 


\section{Bibliography}

Apple, Michael. "Creating Difference: Neo-Liberalism, Neo-Conservatism and the Politics of Educational Reform.” Educational Policy 18, no. 1 (March 2004): 1244.

Apple, Michael. Ideology and Curriculum. $3^{\text {rd }}$ ed. New York, NY: RoutledgeFalmer, 2004.

Baez, Benjamin. "Democracy." Keywords in Youth Studies: Tracing Affects, Movement, Knowledges, edited by Nancy Lesko and Susan Talburt, 153-157. New York, NY: Routledge, 2012.

Baez, Benjamin, and Deron Boyles. The Politics of Inquiry. Albany, NY: State University of New York Press, 2009.

Bennett, David L. "Myth Busting: The Laissez-Faire Origins of American Higher Education." Independent Review 18, no. 4 (Spring 2014): 503-525.

Best, John Hardin. "The Revolution of Markets and Management: Toward a History of American Higher Education since 1945." History of Education Quarterly 28, no. 2 (Summer 1988): 177-189.

Bok, Derek. Higher Education in America. Princeton, NJ: Princeton University Press, 2013.

Brown, Wendy. Undoing the Demos: Neoliberalism's Stealth Revolution. Brooklyn, NY: Zone Books, 2015.

Burbules, Nicholas C., and Bryan R. Warnick. "Philosophical Inquiry." Handbook of Complementary Methods in Education Research, edited by Judith L. Green, Gregory Camilli, and Patricia B. Elmore, 489-502. New York, NY: Routledge, 2006.

Cochran, Clarke E. "Political Science and 'The Public Interest'." Journal of Politics 36, no. 2 (May 1974): 327-355.

Dewey, John. Democracy and Education. New York, NY: Free Press, 1997.

Dewey, John. The Public and its Problems. Athens, OH: Swallow Press, 1954.

Fallis, George. Multiversities, Ideas, and Democracy. Toronto, Canada: University of Toronto Press, 2007. 
Fraser, Nancy. "Rethinking the Public Sphere: A Contribution to the Critique of Actually Existing Democracy." Social Text, no. 25/26 (1990): 56-80.

Foucault, Michel. The Birth of Biopolitics: Lectures at the Collège de France 1978-1979. Edited by Michael Senellart. New York, NY: Palgrave Macmillan, 2008.

Gill, Stephen. "Knowledge, Politics, and Neo-Liberal Political Economy." Political Economy and the Changing Global Order. Edited by Richard Stubbs and Geoffrey R. D. Underhill, 75-88. New York, NY: St. Martin's Press, 1994.

Giroux, Henry A. Neoliberalism's War on Higher Education. Chicago, IL: Haymarket Books, 2014.

Habermas, Jürgen. The Structural Transformation of the Public Sphere: An Inquiry into a Category of Bourgeois Society, translated by Thomas Burger. Cambridge, MA: Massachusetts Institute of Technology, 2000.

Huisman, Jeroen and Jan Currie. "Accountability in Higher Education: Bridge over Troubled Water?" Higher Education 48, no. 4 (December 2004): 529-551.

Hutchins, Robert Maynard. The Higher Learning in America. New Haven, CT: Yale University Press, 1936.

Kerr, Clark. The Uses of the University. $5^{\text {th }}$ ed. Cambridge, MA: Harvard University Press, 2001.

Lafer, Gordon. "The Corporate Assault on Higher Education." Chronicle of Higher Education April 30, 2017. Accessed on August 28, 2017. https://www.chronicle.com/article/The-Corporate-Assault-on/239902.

Levidow, Les. "Neoliberal Agendas for Higher Education" Neoliberalism: A Critical Reader, eds. Alfredo Saad-Filho and Deborah Johnston, 156-162. London: Pluto Press, 2005.

Lippmann, Walter. The Phantom Public. New Brunswick, NJ: Transaction Publishers, 1993.

Mayhew, Matthew, Alyssa Rockenback, Nicholas Bowman, Tricia Seifert, Gregory Wolniak, Ernest Pascarella, and Patrick Terenizini. How College Affects Students: $21^{\text {st }}$ Century Evidence That Higher Education Works. ${ }^{\text {rd }}$ ed. San Francisco, CA: Jossey-Bass, 2016.

Muller, Jerry Z. "The Tyranny of Metrics.” Chronicle of Higher Education January 21, 2018. Accessed January 22, 2018. https://www.chronicle.com/article/TheTyranny-of-Metrics/242269. 
Newman, John Henry. The Idea of a University. Edited by Frank M. Turner. Binghampton, NY: Vail-Ballou Press, 1996.

Pascarella, Ernest T., and Patrick T. Terenzini. How College Affects Students. $2^{\text {nd }}$ ed. San Francisco, CA: Jossey-Bass, 1991.

Pascarella, Ernest T., and Patrick T. Terenzini. How College Affects Students: A Third Decade of Research. San Francisco, CA: Jossey-Bass, 2005.

Perkins, Harold. "History of Universities." International Handbook of Higher Education, edited by James J. F. Forest and Philip G. Altbach, 159-205. New York, NY: Springer, 2007.

Readings, Bill. The University in Ruins. Cambridge, MA: Harvard University Press, 1996.

Rolfe, Gary. The University in Dissent: Scholarship in the Corporate University. New York, NY: Routledge, 2013.

Rudolph, Frederick. The American College and University: A History. Athens, GA: University of Georgia Press, 1990.

Saunders, Daniel. "Exploring a Customer Orientation: Free-Market Logic and College Students." Review of Higher Education 37, no. 2 (Winter 2014): 197-219.

Schramm-Pate, Susan L. and Richard Lussier. "Teaching Students How to Think Critically: The Confederate Flag Controversy in the High School Social Studies Classroom." High School Journal 87, no. 2 (December 2003-January 2004): 5665.

Shor, Ira. "Education is Politics: An Agenda for Empowerment," in Empowering Education: Critical Teaching for Social Change, 11-30. Chicago, IL: University of Chicago Press, 1992.

Slaughter, Sheila. "National Higher Education Policies in a Global Economy" Universities and Globalization: Critical Perspectives. Edited by Jan Currie and Janice Newson, 45-70. Thousand Oaks, SAGE, 1998), 63.

Slaughter, Sheila and Gary Rhoades. "The Policy Climate for Academic Capitalism." Academic Capitalism and the New Economy: Markets, State, and Higher Education, 35-68. Baltimore, MD: Johns Hopkins University Press, 2004.

Tocqueville, Alexis de. Democracy and America. New York, NY: Signet Classics, 2010. 
Veblen, Thorstein. The Higher Learning in America: A Memorandum on the Conduct of Universities by Businessmen. Annotated edition. Baltimore, MD: Johns Hopkins University Press, 2015. 